\title{
Changes in Otx2 and Parvalbumin Immunoreactivity in the Superior Colliculus in the Platelet-Derived Growth Factor Receptor- $\beta$ Knockout Mice
}

\author{
Juanjuan Zhao, ${ }^{1,2}$ Susumu Urakawa, ${ }^{3}$ Jumpei Matsumoto, ${ }^{1}$ Ruixi Li, ${ }^{1,2}$ Yoko Ishii, ${ }^{4}$ \\ Masakiyo Sasahara, ${ }^{4}$ Yuwen Peng, ${ }^{2}$ Taketoshi Ono, ${ }^{3}$ and Hisao Nishijo ${ }^{1}$ \\ ${ }^{1}$ System Emotional Science, Graduate School of Medicine and Pharmaceutical Sciences, University of Toyama, Toyama 930-0194, Japan \\ ${ }^{2}$ Department of Anatomy, Histology and Embryology, Shanghai Medical School, Fudan University, Shanghai 200032, China \\ ${ }^{3}$ Department of Judo Physiotherapy, Graduate School of Medicine and Pharmaceutical Sciences, University of Toyama, \\ Toyama 930-0194, Japan \\ ${ }^{4}$ Department of Pathology, Graduate School of Medicine and Pharmaceutical Sciences, University of Toyama, Toyama 930-0194, Japan
}

Correspondence should be addressed to Hisao Nishijo; nishijo@med.u-toyama.ac.jp

Received 17 July 2013; Accepted 30 September 2013

Academic Editor: Carlos Tomaz

Copyright (C) 2013 Juanjuan Zhao et al. This is an open access article distributed under the Creative Commons Attribution License, which permits unrestricted use, distribution, and reproduction in any medium, provided the original work is properly cited.

\begin{abstract}
The superior colliculus (SC), a relay nucleus in the subcortical visual pathways, is implicated in socioemotional behaviors. Homeoprotein Otx 2 and $\beta$ subunit of receptors of platelet-derived growth factor (PDGFR- $\beta$ ) have been suggested to play an important role in development of the visual system and development and maturation of GABAergic neurons. Although PDGFR- $\beta$ knockout (KO) mice displayed socio-emotional deficits associated with parvalbumin (PV-)immunoreactive (IR) neurons, their anatomical bases in the SC were unknown. In the present study, Otx2 and PV-immunolabeling in the adult mouse SC were investigated in the PDGFR- $\beta$ KO mice. Although there were no differences in distribution patterns of Otx 2 and PV-IR cells between the wild type and PDGFR- $\beta$ KO mice, the mean numbers of both of the Otx2- and PV-IR cells were significantly reduced in the PDGFR- $\beta$ KO mice. Furthermore, average diameters of Otx2- and PV-IR cells were significantly reduced in the PDGFR- $\beta$ KO mice. These findings suggest that PDGFR- $\beta$ plays a critical role in the functional development of the SC through its effects on Otx2- and PV-IR cells, provided specific roles of Otx2 protein and PV-IR cells in the development of SC neurons and visual information processing, respectively.
\end{abstract}

\section{Introduction}

The mammalian superior colliculus (SC) is a seven-layered structure on the roof of the midbrain [1] and can be divided into two functionally distinct units: a superficial subdivision and a deep subdivision $[2,3]$. The superficial layers zonale (ZO), superficial gray (SGR), and optic (OP) layers receive their major inputs from the retina and the visual cortex and are involved exclusively in visual information processing. In contrast, the four deep layers intermediate gray (IGR), intermediate white (IW), deep gray (DGR), and deep white (DW) layers, which receive auditory, somatic, and visual inputs from numerous cortical and subcortical areas, are involved in the control of orientating behaviors of head, eye and ear $[1,4-6]$. Furthermore, recent studies suggest that the subcortical visual pathway including the retina, SC and pulvinar is implicated in socioemotional behaviors $[7,8]$.

Several studies have used parvalbumin (PV) as markers to reveal details of the parallel subcortical pathways involved in visual processing [9]. In the primate lateral geniculate nucleus (LGN), PV is found in the relay cells in the $\mathrm{P}$ and $\mathrm{M}$ pathways [9-11]. In the cat SC, Mize et al. [12] found a band of PVimmunoreactive (IR) cells (PVcells) in the deep SGR and upper OP, a region of the cat SC that receives inputs from $\mathrm{Y}$ retinal ganglion cells [13]. In addition, $\mathrm{PV}$ is also one of the biochemical markers of the matrix surrounding some of the IGR compartments in the SC [14]. Other studies have associated PV with specific firing patterns of neurons, which are 
often found in "fast spiking" neurons with nonadapting trains of action potentials. It has been suggested that PV might regulate a $\mathrm{Ca}^{2+}$-activated $\mathrm{K}^{+}$channel involved in spike adaptation [15], and a particular type of $\mathrm{K}^{+}$channel was developmentally regulated with PV and was expressed in about $80 \%$ of the PVcontaining GABAergic interneurons in the rat hippocampus [16]. Furthermore, deficits in these PV-containing GABAergic interneurons were associated with schizophrenia and autism with social deficits $[17,18]$, and the number of PVpositive neurons was reduced in the SC of an animal model of autism with prenatal valproic acid exposure [19].

The Otx2 homeobox gene is a vertebrate orthologue of the Drosophila orthodenticle gene [20-22]; members of this orthology group play a fundamental role in development of photoreceptors Otx 2 and Crx (cone-rod homeobox) and rostral brain regions (Otxl and Otx2) [23, 24]. Otx2 also appears to play a role in development and function of the retina, in which the gene is expressed at both prenatal and postnatal stages [25-29]. In addition, Otx2 coordinates postnatal PVcell maturation and activates visual cortical plasticity [30]. Otx2 is strikingly restricted to relay centers in the primary visual pathway at birth before PV-cells are evident [31], including the retina, LGN, and visual cortex (V1). Furthermore, exogenous Otx2 infusion accelerated PV-cell development in the V1 area [30]. These findings indicate that Otx2 is related to development of the visual system. However, to our knowledge, no information is available concerning Otx2 expression in the retinocollicular (retinotectal) visual pathway in adult mice. It is possible that Otx2 may control functional features of SC neurons in adult mice.

Platelet-derived growth factor (PDGF) was originally reported as a substance in platelets that promote growth of tissue culture cells [32]. However, the factor is recently reported to act as a neuroprotective factor in the central nervous system (CNS) [33-36]. PDGF is also involved in the regulation of cell growth and differentiation during embryonal development [37-39]. The family of plateletderived growth factors (PDGFs) comprises 4 membersPDGF-A, -B, -C, and -D—that are assembled from disulfidelinked homo- or heterodimers of 2 distinct but related chains (PDGF-AA, -AB, -BB, -CC, and -DD). Two receptor subtypes of PDGF (PDGFR- $\alpha$ and $-\beta$ ) can form mature dimeric receptor complexes that can bind to ligands with different affinities [40]. PDGFR- $\alpha$ is largely expressed in oligodendroglial progenitors, while PDGFR- $\beta$ is predominantly expressed in neurons [41] and upregulated in the neonatal rat brain [42]. PDGF-BB that specifically binds to PDGFR$\beta \beta$ is abundantly expressed in neurons and is upregulated in neonatal brains $[33,43,44]$. PDGF-B exerts neurotrophic effects on $\gamma$-aminobutyric acid GABA ergic neurons [42, 45]. Altering PDGFR- $\beta$ may result in abnormalities during the development of the CNS [46, 47]. Consistently, conditional knockout $(\mathrm{KO})$ mice with suppressed expression of neuronal PDGFR- $\beta$ in the Cre/loxP system (PDGFR- $\beta$ KO mice) displayed autistic/schizophrenic traits, especially deficits in socioemotional behaviors [48].

Taken together, there is a possible link among PV, Otx2, and PDGFR- $\beta$, and behavioral deficits in the PDGFR- $\beta$
$\mathrm{KO}$ mice might be ascribed to changes in PV and Otx2 in the SC. In the present study, to investigate the role of PDGFR- $\beta$ in Otx 2 and PV expression in the SC, we analyzed immunohistochemical alterations in Otx 2 and $\mathrm{PV}$ expression in the SC of PDGFR- $\beta$ KO mice.

\section{Materials and Methods}

2.1. Generation of the Conditional PDGFR- $\beta$ Knockout Mice. The Cre/loxP system was used to develop conditional PDGFR- $\beta$ KO mutants. A previously established mutant mouse line was used, in which exons $4-7$ of PDGFR- $\beta$, which encode the extracellular domain of the PDGFR- $\beta$ protein, were flanked by 2 loxP sequences (floxed) positioned in introns 3 and 7 [49]. After Cre-mediated recombination, deletion of the loxP-flanking region and resulting frame shift mutation in the adjoining $3^{\prime}$ region occurred in PDGFR$\beta$. To obtain conditional PDGFR- $\beta \mathrm{KO}$, we then crossed mutant mice harboring the PDGFR- $\beta$ floxed allele and those expressing Cre recombinase under the control of the nestin promoter and enhancer (nestin-Cre+ mouse, The Jackson Laboratory, Bar Harbor, ME, USA) as previously described $[50,51]$. Before this cross, both mutant mice harboring floxed PDGFR- $\beta$ and nestin-Cre+ were outbred to the mice of $\mathrm{C} 57 \mathrm{BL} / 6 \mathrm{~J}(\mathrm{~B} 6 / \mathrm{J})$ strain for 14 generations to replace the genetic background of our mutant mice with that of the B6/J strain. In the present study, the following 2 types of 22 to 29 weeks old male mice were used: mice with the Cre transgene and floxed PDGFR- $\beta$ (PDGFR- $\beta$ KO mice) and mice without the Cre transgene but with floxed PDGFR- $\beta$ (control mice).

Genotypes were confirmed by PCR of tail DNA, using oligonucleotide primers pairs for floxed PDGFR- $\beta$ and for the Cre transgene as described previously [50]. The genotyping was confirmed by Western blot of the total lysates of the adult mouse brains to show that the PDGFR- $\beta$ expression decreased to undetectable levels in the PDGFR- $\beta$ KO mice compared with that in the control mice [50].

In the present study 6 control mice (24-28 weeks old, 22$29 \mathrm{~g}$ body weight) and 4 PDGFR- $\beta$ KO mice (24-28 weeks old, $22-29 \mathrm{~g}$ body weight) were used. All mice were housed in individual cages in a temperature-controlled environment with a 12/12 h light/dark cycle (lights were turned on and off at 08:00 and 20:00, resp.). Food and water were supplied ad libitum. Mice (10 to 16 weeks old) were handled for 3 consecutive days before the start of the experiments. All experimental protocols were performed in accordance with the guidelines for Care and Use of Laboratory Animals approved by the University of Toyama and the National Institutes of Health's Guide for the Care and Use of Laboratory Animals, and approved by the Committee for Animal Experiments at the University of Toyama.

2.2. Perfusion and Tissue Processing. Under deep anesthesia with sodium pentobarbital ( $50 \mathrm{mg} / \mathrm{kg}$ body weight, i.p.), the mice were transcardially perfused with heparinized saline $(0.9 \% \mathrm{w} / \mathrm{v} \mathrm{NaCl})$, followed by $4 \%$ paraformaldehyde dissolved in $0.1 \mathrm{M}$ phosphate buffer (PB), $\mathrm{pH}$ 7.4. After perfusion, the brains were removed from the skull, cut coronally into 
small blocks and postfixed in $4 \%$ paraformaldehyde for overnight. The fixed brain blocks were immersed into $30 \%$ sucrose in $0.1 \mathrm{M}$ PB until they sank down on the bottom. The brain blocks were freezed in dry ice and coronally cut into sections at the thickness of $40 \mu \mathrm{m}$. The sections were collected in $0.01 \mathrm{M}$ PBS and then transferred into a cryoprotectant solution (25\% ethylene glycol, 25\% glycerin, and 50\% $0.1 \mathrm{M} \mathrm{PBS}$ ) and stored at $-20^{\circ} \mathrm{C}$ until immunohistochemical staining.

2.3. Immunohistochemistry of the Sections. Three serial sections were collected every $120 \mu \mathrm{m}$, two for PV and Otx2immunocytochemistry and one for Nissl staining with cresyl violet. The sections were washed thrice in $0.01 \mathrm{M}$ phosphate buffer saline (PBS) for $15 \mathrm{~min}$, blocked with 3\% normal horse serum $0.25 \%$ Triton $\mathrm{X}-100$ in PBS for $30 \mathrm{~min}$ at room temperature, and incubated overnight at $4^{\circ} \mathrm{C}$ with mouse monoclonal anti-PV (1:10,000 dilution, Sigma, St. Louis, MO, USA) or goat polyclonal anti-Otx2 (1:200 dilution, $\mathrm{R} \& \mathrm{D})$ antibodies in $1 \%$ blocking solution $0.25 \%$ Triton $\mathrm{X}-$ 100 in PBS. These sections were washed thrice with $0.01 \mathrm{M}$ PBS for $5 \mathrm{~min}$ each time, incubated with biotinylated horse anti-mouse IgG or anti-goat IgG (1:250 dilution, Vector, Burlingame, USA) for $1 \mathrm{hr}$ at room temperature, and then, after washing, incubated in $\mathrm{ABC}$ reagent (Vector) for $50 \mathrm{~min}$. Finally, the PV- and Otx2-immunoreactive elements were

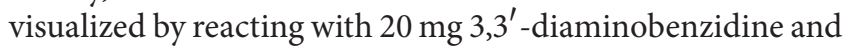
$20 \mu \mathrm{L} 30 \% \mathrm{H}_{2} \mathrm{O}_{2}$ in $100 \mathrm{~mL} 0.05 \mathrm{M}$ PBS ( $\mathrm{pH} \mathrm{7.6)} \mathrm{for} \mathrm{5-}$ $8 \mathrm{~min}$. The sections were then rinsed several times in PBS, dehydrated in graded concentrations of ethanol, cleared in xylene, and cover-slipped with Entellan (Merck, Darmstadt, Germany). To minimize variability in staining, the sections from the all treatment groups were run in the same immunocytochemistry session. Negative control sections were treated identically except for omission of the primary antibody. No reaction product was observed in any of the control sections.

The corresponding adjacent sections were stained with cresyl violet to identify colliculus layers. The colliculus layers were identified by staining and cellular densities and morphologies of SC neurons [1]. We also identified collicular layers using parvalbumin-labeled sections where the collicular layers of these proteins have been well described previously $[12,52,53]$.

2.4. Identification of the SC and Image Capture. In each section, the SC was identified and subdivided into collicular layers. The nomenclature of the mouse atlas of Patrick and Warren (2000) was adopted. Labeling was examined using standard bright-field microscope (BX 61; Olympus, Tokyo, Japan) with different magnifications (4 100x). A series of images of the SC were captured by a digital camera (DP 70, Olympus, Tokyo).

2.5. Data Analysis. In the present study, 6 coronal sections $(-3.30,-3.62,-3.94,-4.26,-4.58$, and $-4.90 \mathrm{~mm}$ from the bregma) in each mouse were analyzed for quantification of Otx2- and PV-IR cells. These digital images were analyzed using the ImageJ software (NIH ImageJ; http://rsbweb.nih .gov/ij/). The mean number of cells per section in each layer was estimated based upon two approache the measurement of pixel intensity and counting of immunopositive cells. For the pixel intensity of immunopositive cells, all images used for cell quantification were saved as uncompressed 8bit grey-scale tiff files and then were thresholded using the autothreshold tool in ImageJ, with visual comparison being made to the original grey-scale images to ensure that the tool effectively resolved all labeled cell somas or nuclei. Therefore, particle analysis was carried out using the analyze particle tool. The mask tool was used to confirm that all particles (labeled cell somas or nuclei) were detected and measured.

Estimates of cell number in two-dimensional sections are subject to error and bias, which can be partially overcome by use of the Abercrombie correction $[54,55]$. To enable such a correction in the current study, sections were cut at thickness of $40 \mu \mathrm{m}$, and nuclear diameter of Otx2-IR cells and soma diameters of PV-IR cells (the average of long and short axes) were computed by measuring the long and short axes of cells counted. The correction factor was then applied to all cell measurements. The assessments were carried out by a single investigator (JJ Z), blind to group status. In order to furthermore diminish variability, rating of images was performed on 10 different occasions by the same blinded observer. Great care was taken to match sections through the same region of the brain and at the same level using the anatomical landmarks. Layers of the SC were identified using the counterstained sections of both the control and $\mathrm{KO}$ mice and then outlined using commercial software (Corel Draw 12). The collicular layers traced as above were analyzed on the corresponding collicular areas of immunocytologically processed control and $\mathrm{KO}$ mice.

We analyzed the mean number of cells in each layer (6 sections from each of the 6 control mice and $4 \mathrm{KO}$ mice) the diameter of each cell counted (6 sections from each of the 4 control mice and $4 \mathrm{KO}$ mice), and categorized cells as vertical and horizontal fusiform, pyriform, marginal (round), and multipolar cells according to the previous studies [56, 57]. All statistical comparisons ( $t$-test and repeated measure ANOVA) were performed using SPSS 17.0 software. A value of $P<0.05$ was considered to be significant.

\section{Results}

3.1. Distribution of Otx2- and Parvalbumin (PV-) Immunoreactive (IR) Cells in the SC. Figure 1 shows the location of the SC in the coronal (a) sections of the mouse brain atlas and a section stained by cresyl violet (b) indicating different subdivisions of the SC. Neuroanatomically, the SC has two divisions: a superficial subdivision comprising the zonal (ZO), superficial gray (SGR), and optic (OP) layers and a deep subdivision comprising the intermediate gray, intermediate white, deep gray, and deep white layers. The two layers of white matter in the deep subdivision are often rather indistinct and do not appear to demarcate cellular distributions. Therefore, we simply divided the deep subdivision into two regions: the intermediate gray (IGR) layer and the deep layers (DLs) including the deep white, deep gray, and intermediate white layers. 


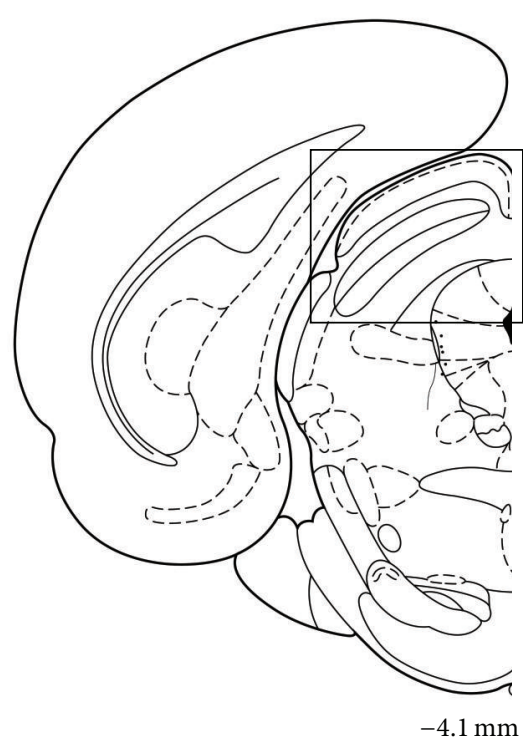

(a)

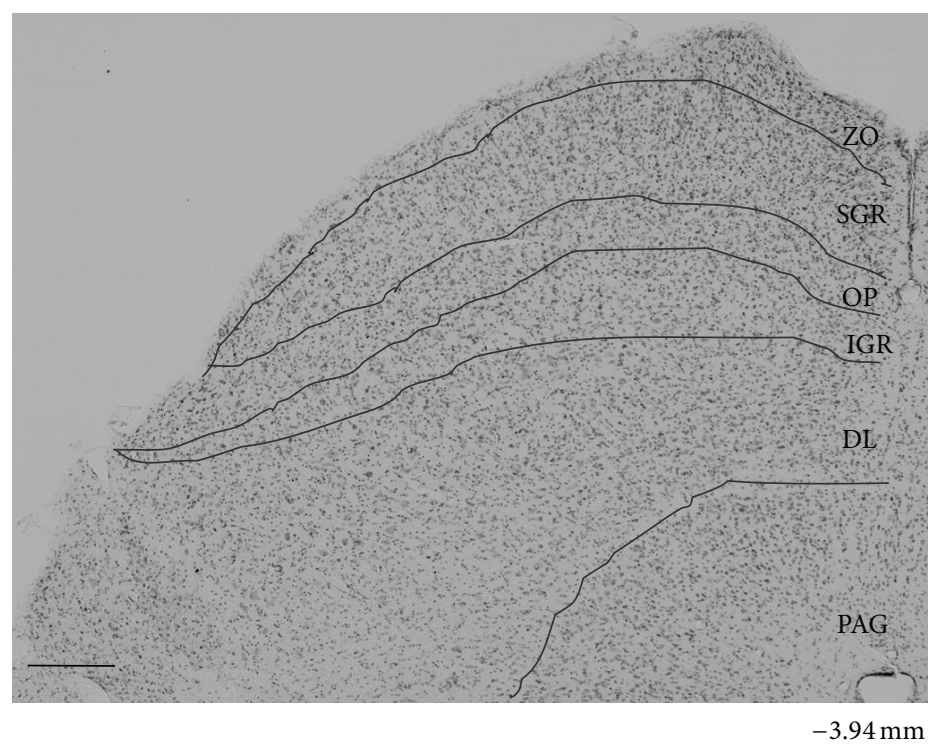

(b)

FIGURE 1: Coronal section in the brain atlas (AP, $-4.1 \mathrm{~mm}$ from the bregma) (a) and representative section stained with cresyl violet (AP, $-3.94 \mathrm{~mm}$ from the bregma) (b) showing the location and laminar pattern of the mouse SC. The square in A indicates the SC region. ZO zonale; SGR superficial gray layer; OP optic; IGR intermediate gray layer; DL, deep layer; and PAG periaqueductal gray matter. Scale bar = $200 \mu \mathrm{m}$.

Figure 2 illustrates low power photomicrographs of the control mouse SC sections stained with Otx2 antibody (A) and PV antibody (B) indicating the laminar distributions of Otx2 and PV-IR cells. Figure 3(a) shows black and white photomicrographs of the rostral SC sections stained with Otx2 (a) and PV (b) antibodies in the control mice as a function of the threshold intensity. The image data were thresholded to highlight the labeled cell somas or nuclei. Figure 4(a) indicates high-magnification photomicrographs of the Otx2-labeled sections in the superficial (A) and deep main (B) layers of the SC in the control mice. The patterns of Otx2 and PV labeling in the present study were different from each other. Otx2-IR cells were found in all layers of the SC, but more densely in the superficial layers. PV-IR cells were also observed in all layers of the SC, but different from that of Otx2-IR cells (see below in detail).

The dense distribution of Otx2-IR cells was found in the superficial layers (ZO, SGR, and OP) (Figures 2(a), 3(a)(A), and $4(\mathrm{a})(\mathrm{A}))$. Otx2-IR cells were also observed in the deep layers (IGR, and DL) (Figures. 2(a), 3(a)(A), and 4(a)(B)), which mainly included lightly labeled, small to mediumsized cells (Figure 4(a)(B)). In contrast, very few labeled cells were observed in the areas surrounding the SC. The similar distribution patterns of Otx2-IR cells were observed through the rostral-caudal extent of the SC (Figure 2(a)).

Figure 5(a) indicates high-magnification photomicrographs of the PV-labeled sections in the superficial (A) and deep main layers (B, C) of the control mouse SC. $\mathrm{PV}$-IR cells were concentrated within the superficial layers of the SC, with a heavier frequency within SGR than in the OP (Figure 5(a)(A). Also see Figures 2(b) and 3(a)(B)). Labeled IR elements in the dense tier included not only lightly stained small-to-medium sized somas but also proximal dendrites and small immunoreactive puncta that could be axons, axon terminals, or small dendrites (open triangles) (Figure 5(a)(A)). PV-IR cells were also scattered throughout the deep layers below the dense tier. In the lateral part of the IGR, clusters of PV-IR cells (arrows) were observed in the immunoreactive fiber patches (open triangles) (Figure 5(a)(B)). Scattered medium-to-large PV-IR cells (arrows) were found in the DL (Figure 5(a)(C)), including a few that are immediately adjacent to the periaqueductal gray and, occasionally, in the ZO. The neuropil labeling was patchy in the IGR and moderate in the DL (Figure 2(b)).

\subsection{Morphology of the Otx2- and PV-IR Cells in the Control} Mice. Figure 4(a)(C) represents various types of Otx2-IR cells in the control mouse SC. The principal cell types in the mouse SC labeled with Otx2 antibody were dark or light round to oval cells. These labeled IR elements were located in the nucleus of the cell body, consistent with a previous study $[30,58]$. However, ratios of the strongly and weakly stained cells varied between the superficial and deep layers of the SC. In the superficial layers of the SC, a large majority of Otx2IR cells were composed of the strongly stained cells. In the deep layers of the SC, most of the labeled cells were weaker and smaller compared with those observed in the superficial layers of the SC. Furthermore, there were some differences in diameter (the average of long and short axes) between the two divisions. The average diameter of Otx2-IR cells in the superficial layers of the SC ranged from 3.26 to $9.00 \mu \mathrm{m}$ with a mean of $6.01 \mu \mathrm{m}$. The average diameter of Otx2-IR cells in the deep layers of the SC ranged from 3.17 to $8.50 \mu \mathrm{m}$ with a mean of $5.75 \mu \mathrm{m}$. Statistical comparison indicated that 


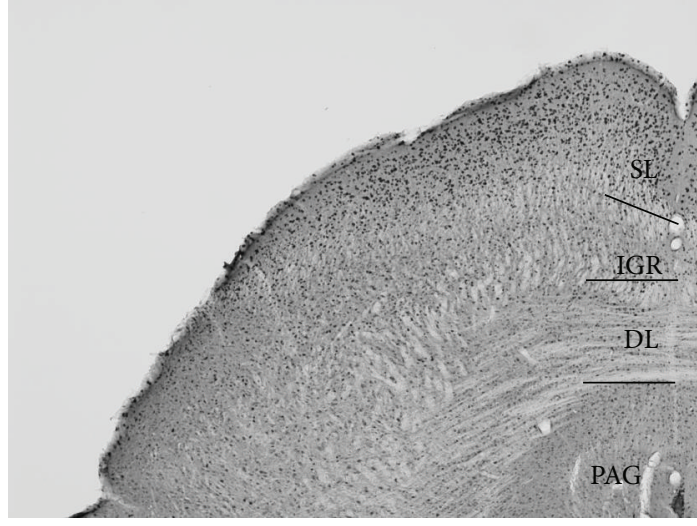

(A)

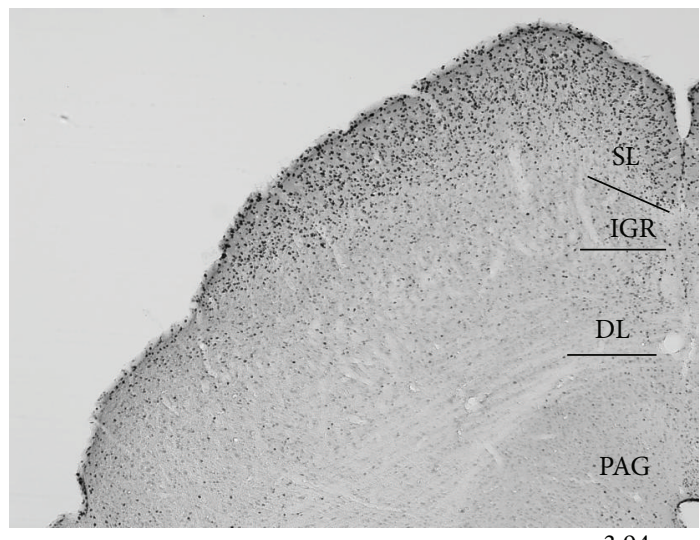

(B)

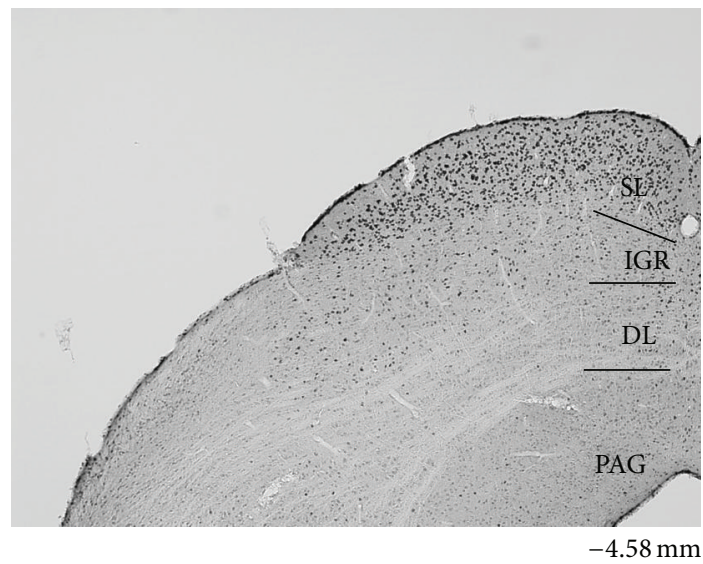

(C)

(a) Otx2

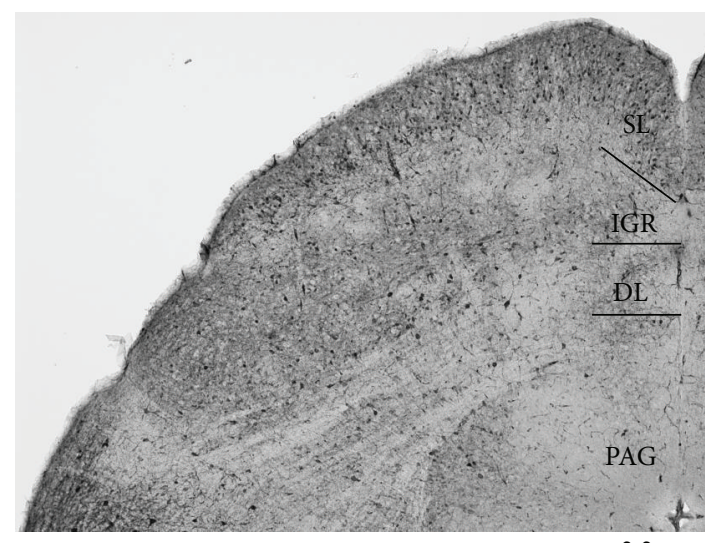

(A)

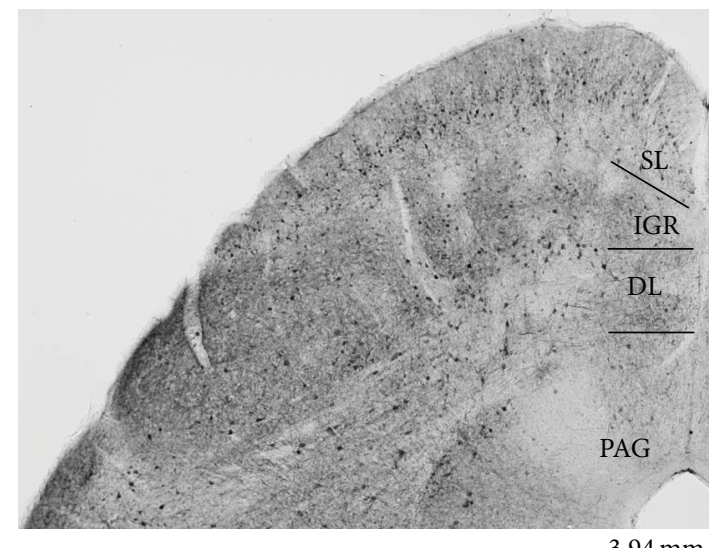

(B)

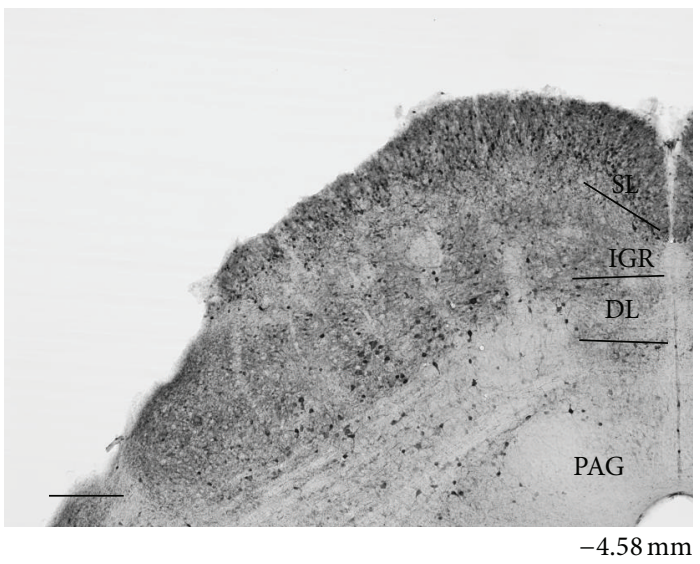

(C)

(b) PV

FIGURE 2: Low power photomicrographs of the laminar distribution of Otx2-IR (a) and parvalbumin (PV-) IR (b) elements in the control mouse SC. Two matching series of left coronal sections in 3 AP levels (A-C) are presented. Note prominent Otx2-IR cells in the superficial layers (SLs) and scattered Otx2-IR cells in the intermediate gray layer (IGR) and deep layers (DLs). Also note strong PV-labeling in the SL, patchy PVlabeling in the IGR, and scattered and/or clustered PV-IR cells in the IGR and DL. Number below each section indicate distance from the bregma. PAG periaqueductal gray matter. Scale bar $=200 \mu \mathrm{m}$. 


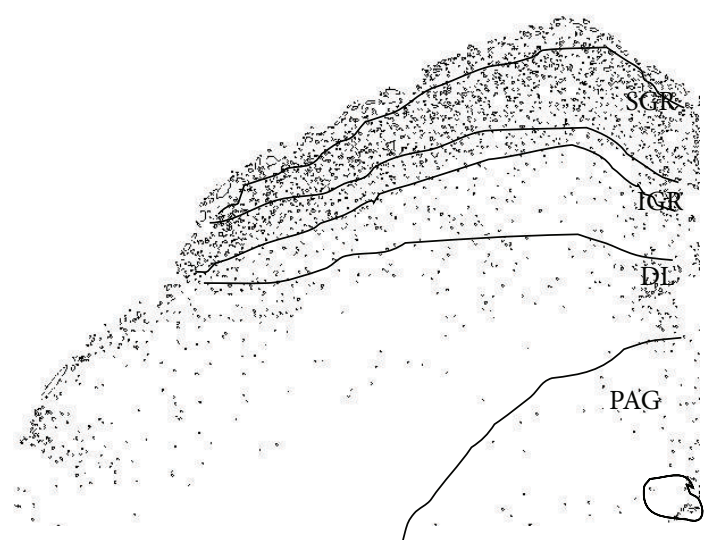

(A) Otx2

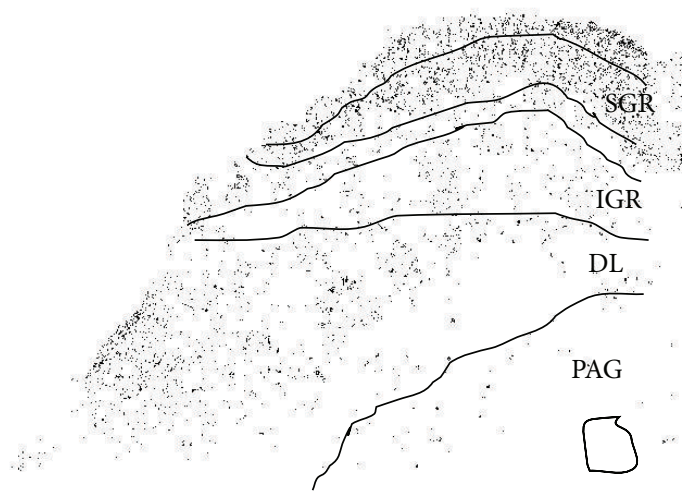

(B) PV

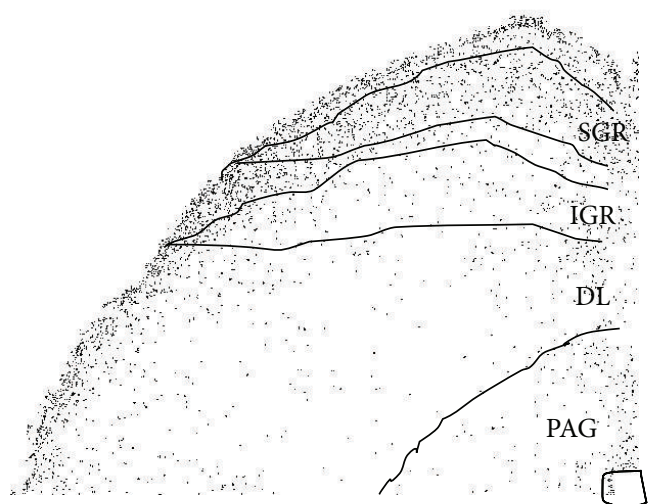

(A) Otx2

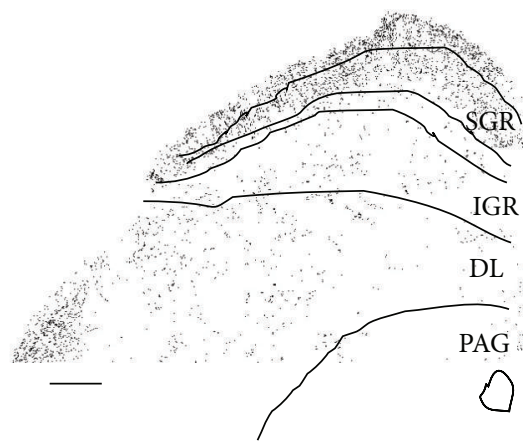

(B) $\mathrm{PV}$

(b) $\mathrm{KO}$

(a) Control

FIGURE 3: Distribution of Otx2-IR (A) and parvalbumin (PV-) IR (B) cells in the control (a) and KO (b) mice. Image data were masked by threshold intensity using ImageJ. SGR superficial gray; IGR intermediate gray layer; DL deep layer; PAG periaqueductal gray matter. Scale bar $=200 \mu \mathrm{m}$.

the mean sizes of Otx2-IR cells were significantly larger in the superficial layers than those in the deep layers (unpaired $t$ test, $P<0.001$ ).

Figure 6 represents various types of PV-IR cells in the control mouse SC. We categorized the PV-IR cells as vertical and horizontal fusiform, pyriform, marginal (round), and multipolar cells according to the previous studies [56,57]. The types of PV-IR cells identified in the mouse SC were more variable than the classes of Otx2-IR cells. These labeled cells consisted of at least four distinct morphologies. Marginal cells had small, roundish, or stellate soma with few or no labeled dendrites (a). These cells were the most prominent type in the superficial layers of the mouse SC. Pyriform (pyramidal) cells had pear-shaped soma with one tufted dendritic tree extending above the cell body (b). This cell type was located mostly in the ventral SGR, IGR, and DL.

Horizontal fusiform cells had horizontally elongated triangular or fusiform cell, with stout dendrites coursing in the same plane as the cell body (c). These cells were found mostly in the dorsal OP and in the lateral region of the DL. Vertical fusiform cells had vertical fusiform soma, usually with one dendrite emanating vertically from each pole (d). These cells were located mostly in the ventral SGR.
Fourth type of the PV-IR cells was multipolar cells with large, lightly stained multipolar soma and several dendrites that radiated from the soma (e). These cells were observed in the IGR and DL.

Furthermore, the three layers had their corresponding diameters. The average diameter of PV-IR cells in the superficial layers of the SC ranged from 6.08 to $21.62 \mu \mathrm{m}$ with a mean of $9.13 \mu \mathrm{m}$. In the IGR, the diameter of labeled cells ranged from 6.08 to $20.27 \mu \mathrm{m}$ with a mean of $10.76 \mu \mathrm{m}$. In the DL of the SC, the diameter of PV-IR cells ranged from 7.03 to $21.62 \mu \mathrm{m}$ with a mean of $12.91 \mu \mathrm{m}$. Statistical analysis indicated that there was a significant difference in cell size among the 3 laminae $(P<0.001$, Bonferroni tests after repeated measures one-way ANOVA).

3.3. Otx2 and PV Expression in the PDGFR- $\beta$ KO Mice. Comparison of the control and $\mathrm{KO}$ mice revealed similar distribution patterns of Otx2- and PV-IR cells in the SC (Figure 3), in which the image data were thresholded to highlight the labeled cell somas or nuclei. Thus, two distinctive tiers of Otx2-IR labeling in the KO mouse SC (Figure 4(b)) were virtually identical to those in the control 


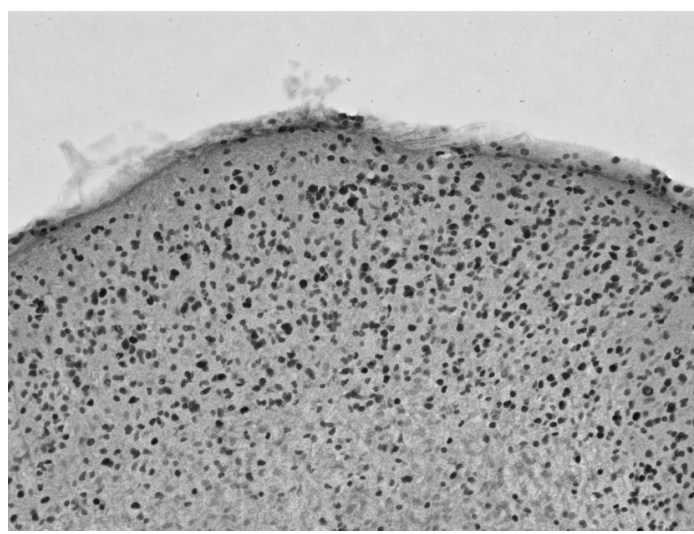

(A) Superficial layers

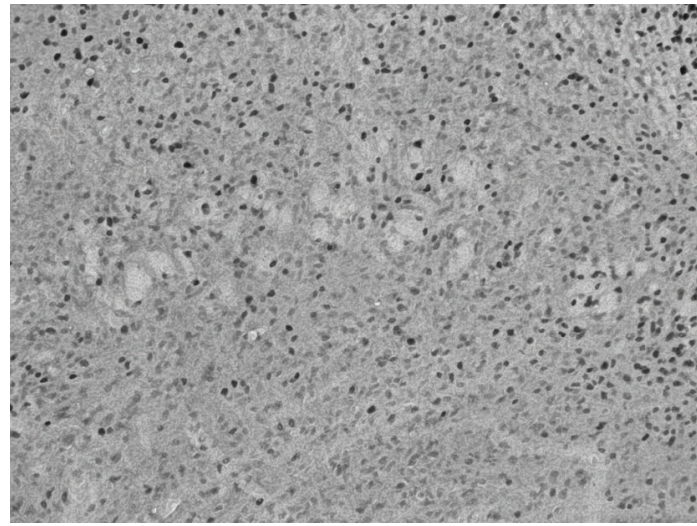

(B) Deep layers

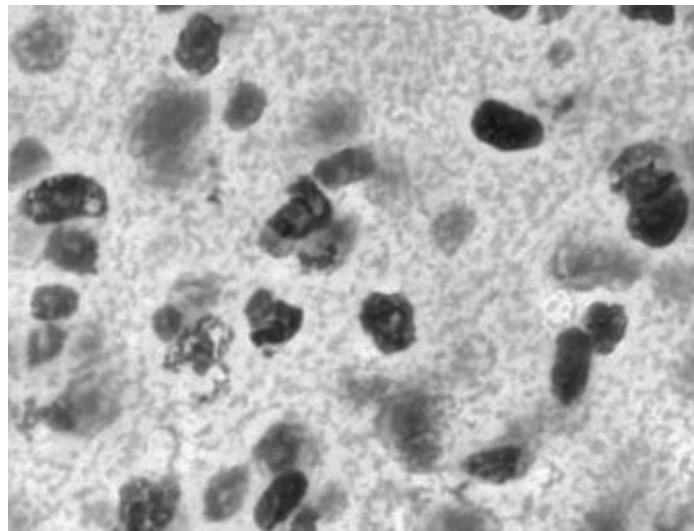

(C)

(a) Control (Otx2)

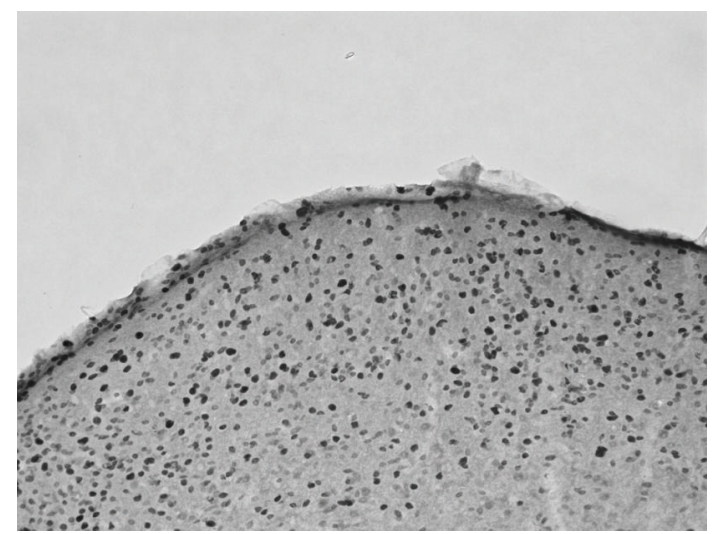

(A) Superficial layers

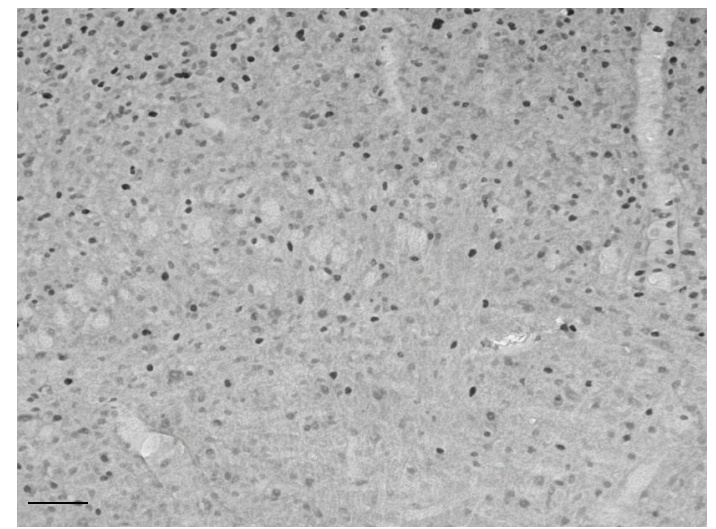

(B) Deep layers

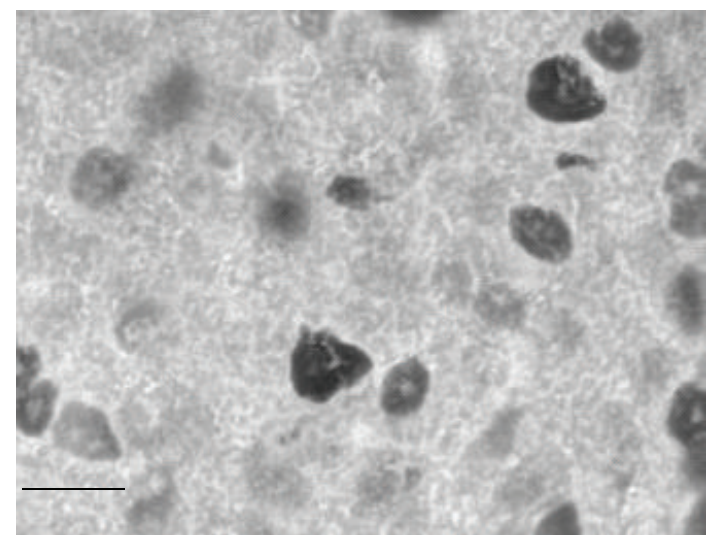

(C)

(b) $\mathrm{KO}(\mathrm{Otx} 2)$

FIGURE 4: High-magnification photomicrographs of the Otx2-labeled sections in the control (a) and KO (b) mice. (a, b) Photomicrographs in the superficial (A) and deep main (B) layers of the SC. Note that the darklylabeled small-to-medium cells are densely distributed in the superficial layers in the SC of the control mouse. Similar patterns of distribution of Otx2-IR cells are also observed in the KO mice, but fewer Otx2-IR cells are observed in the KO mice. Scale bar $=60 \mu \mathrm{m}$. (C) Higher-magnification photomicrographs of the Otx2-IR cells in the optic (OP) layer. Note oval- or round-shaped Otx2-IR cells. IRelements are localized in the nucleus of the cell body. Orientation of the images is dorsal to the top and lateral to the left. Scale bar $=10 \mu \mathrm{m}$.

mice (Figure 4(a)). The band of densely labeled, small-tomedium-sized PV-IR cells in the superficial layers (SGR and $\mathrm{OP}$ ) was also present in the KO mice (Figure 5(b)(A)). Clusters of PV-IR cells surrounded by the patchy fiber in the
IGR were also visible in the KO mice (Figure 5(b)(B)). We also observed scattered medium-to-large PV-IR cells in the DL of the KO mouse SC (Figure 5(b)(C)). Tables 1 and 2 reveal mean number of Otx2- and PV-IR cells in each layer of the 


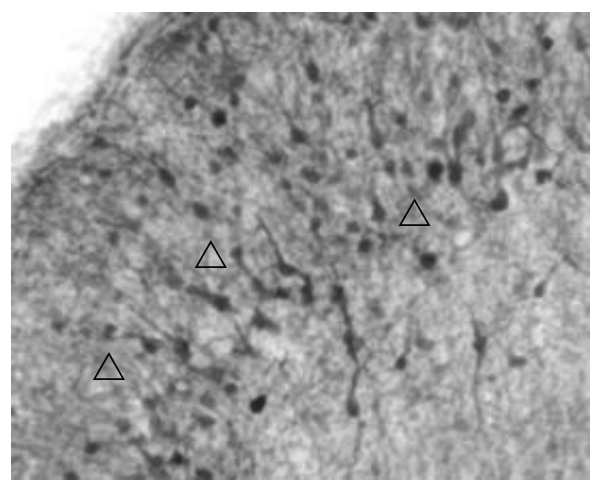

(A) Superficial layers

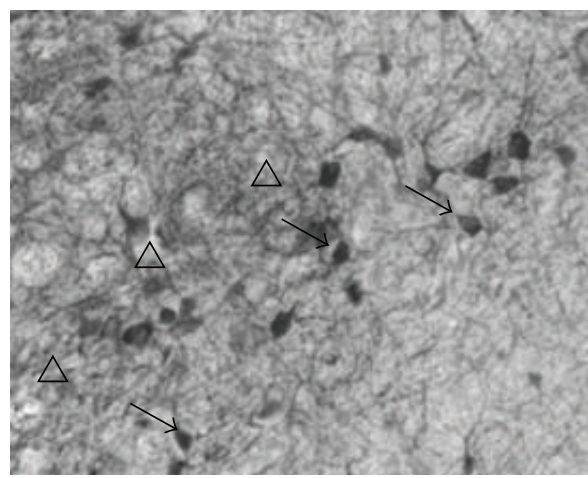

(B) Deep layers (IGR)

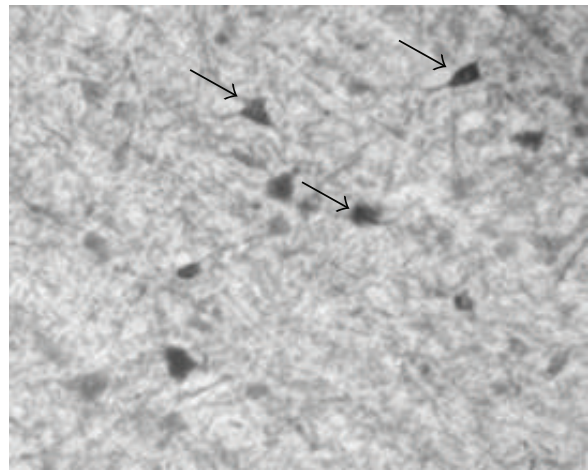

(C) Deep layers (DL)

(a) Control (PV)

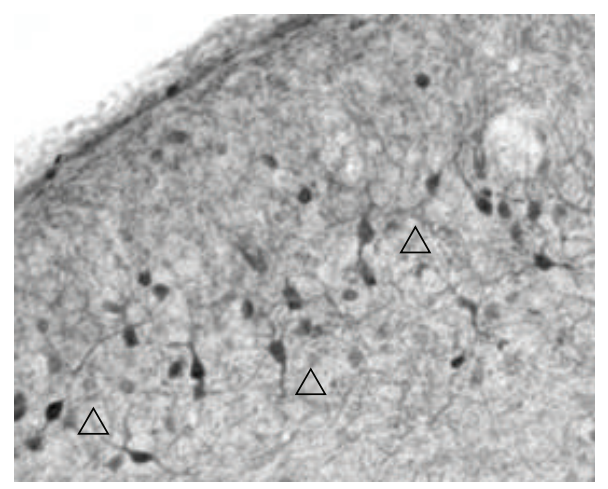

(A) Superficial layers

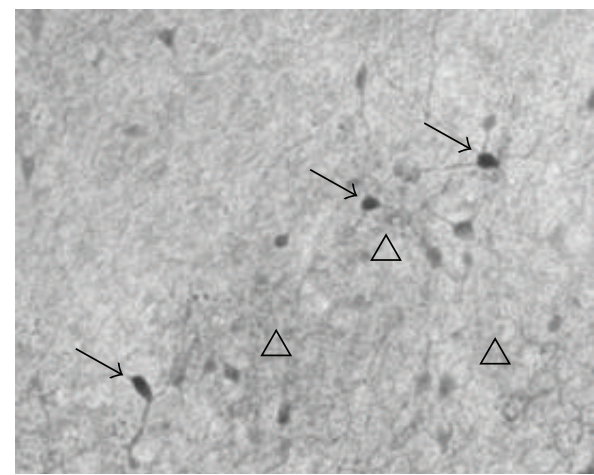

(B) Deep layers (IGR)

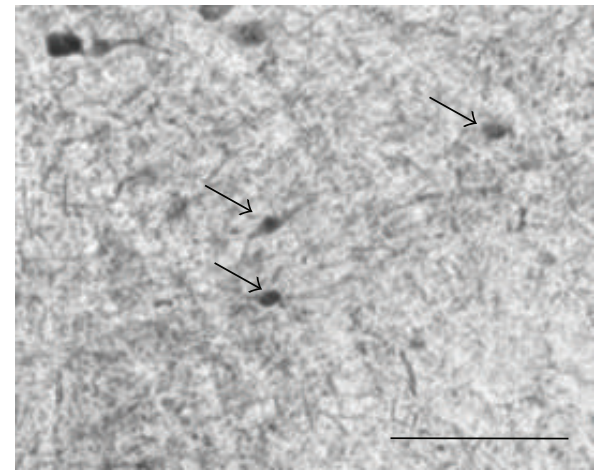

(C) Deep layers (DL)

(b) $\mathrm{KO}(\mathrm{PV})$

FIGURE 5: High-magnification photomicrographs of the PV-labeled sections in the superficial layers (A), IGR (B) and DL (C) of the control (A) and KO (B) mouse SC. Note a dense band in the deep SGR and the upper OP (open triangles) (A), clusters of PV-IR cells (arrows) and the intense PV-IR neuropils (open triangles) in the IGR (B), and scattered PV-IR cells (arrows) in the DL (C) in the control mouse (a). Similar patterns of distribution of PV-IR cells are also observed in the KO mice (b), but fewer PV-IR cells and less intense PV-IR neuropils are observed. Orientation of the images dorsal to the top and lateral to the left. SGR superficial gray; OP optic; IGR intermediate gray layer; is DL and the deep layers. Scale bar $=60 \mu \mathrm{m}$.

mouse SC. Cell counts in each layer indicated that frequency distributions of the labeled cells were similar in the control and $\mathrm{KO}$ mice (Tables 1 and 2).

Furthermore, Figures 4(b)(C) and 7 show high-magnification photomicrographs of Otx2- and PV-IR cells in the KO mice, respectively. All the various morphological Otx2- and $\mathrm{PV}$-IR cell types in the control mice were also identified in the KO mouse SC. Thus, Otx 2 antibody labeling in the KO mouse SC revealed dark or light round to oval cells (Figure 4(b)(C)). All the PV-IR cell types found in the SGR and OP in the control mice were also present in the KO mice (Figure 7). Marginal cells with star-shaped cell bodies and few or no labeled dendrites were commonly observed (a), and several pyriform cells were also found in the KO mouse SGR and OP (b, c). Vertical fusiform cells were also frequently seen in the SGR regions of the KO mice (d). Horizontal fusiform cells were observed in the KO mouse OP (f), each having a horizontally elongated cell body and two stout dendrites coursing from the cell body. The PV-IR cells in the KO mouse IGR were large and clustered (Figure 5(b)(B)), just as in the control 


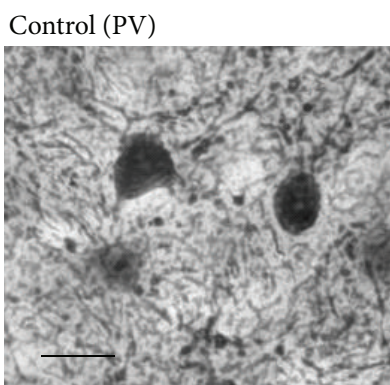

(a)

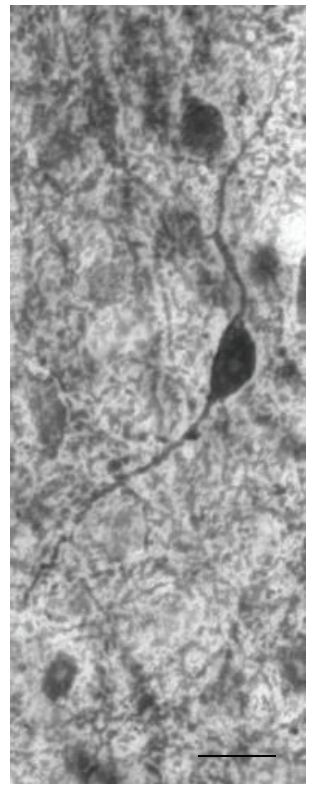

(d)

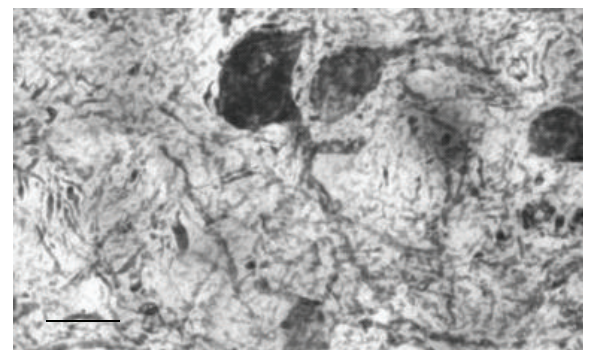

(b)

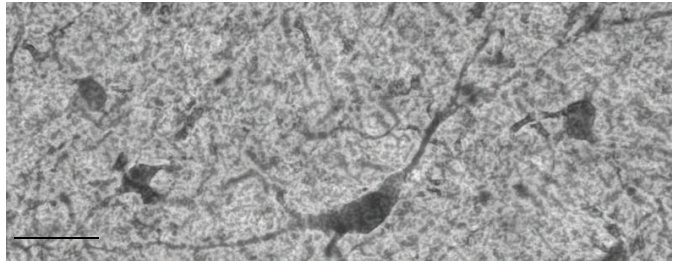

(c)

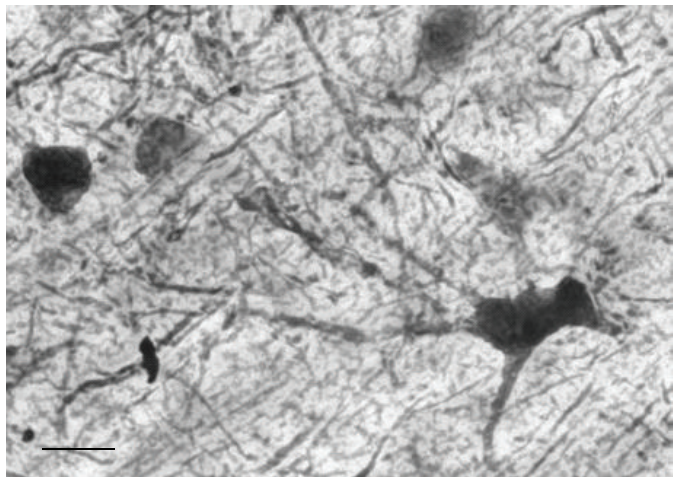

(e)

FIGURE 6: Representative examples of high-magnification photomicrographs of PV-IR cells in the control mouse SC. (a) Labeled soma of marginal PV-IR cells in the deep superficial gray (SGR). (b) Pyriform PV-IR cell in the PV-IR fiber patch in the lateral intermediate gray layer (IGR). (c) Horizontal fusiform cell in the lateral region of the deep layers (DL). (d) Vertical fusiform cell in the ventral SGR. (e) Large multipolar PV-IR cell in the DL. Orientation of the images is dorsal to the top and lateral to the left. Scale bars $=10 \mu \mathrm{m}$.

mouse IGR. Finally, PV-IR cells in the KO mouse DL consisted of both multipolar (e) and horizontal fusiform (f) cells.

\subsection{Effects of the PDGFR- $\beta$ Gene on Otx2 and PV Expres-} sion. Although the basic cell types and laminar distribution patterns of Otx2 and PV antibody labeling in the $\mathrm{KO}$ mice were similar to those in the control mice (see above), the following quantitative analyses indicated significant differences between the control and KO mice. Figure 8(a) indicates distributions of average diameter of the Otx2-IR cells in the control and KO mouse SC. The average diameter of Otx2IR cells in the whole control SC ranged from 3.17 to $9.00 \mu \mathrm{m}$ with a mean of $5.88 \mu \mathrm{m}$. Figure $8(\mathrm{~b})$ revealed distribution of the diameter of PV-IR cells in the whole control SC ranging from 6.08 to $20.27 \mu \mathrm{m}$ with a mean of $10.85 \mu \mathrm{m}$. The mean average diameters of Otx2- and PV-IR cells in the KO mouse $\mathrm{SC}$ were smaller than those in the control mouse (unpaired $t$-test, $P<0.001)$.

Figure 9(a) shows the number of Otx2-IR cells observed in the 6 coronal levels of the SC in the control and $\mathrm{KO}$ mice.
Statistical analysis by repeated measures two-way ANOVA indicated that the mean number of the Otx2-IR cells in the whole SC was significantly reduced in the $\mathrm{KO}$ mice compared with the control mice $F(1,40)=81.098, P<$ 0.001 (Figure $9(\mathrm{a})$ ). This trend was also evident in the data processed by threshold mask in Figures 3(a)(A) and 3(b)(A). Mean numbers of the Otx2-IR cells per section in each lamina were also significantly decreased in the $\mathrm{KO}$ than those in control mice (unpaired $t$-test) (Table 1).

Figure 9(b) shows the number of PV-IR cells observed in the 6 coronal levels of the SC of the control and $\mathrm{KO}$ mice. Statistical analysis by repeated measures two-way ANOVA indicated that the mean number of the PV-IR cells in the whole SC was significantly reduced in the $\mathrm{KO}$ mice compared with the control mice $F(1,40)=83.558, P<$ 0.001 (Figure 9(b)). This trend was also evident in the data processed by threshold mask in Figures 3(a)(B) and 3(b)(B). Statistical comparisons indicated that the average numbers of PV-IR cells were significantly decreased in each SC lamina of the $\mathrm{KO}$ mice except the $\mathrm{ZO}$ (unpaired $t$-test) (Table 2). 


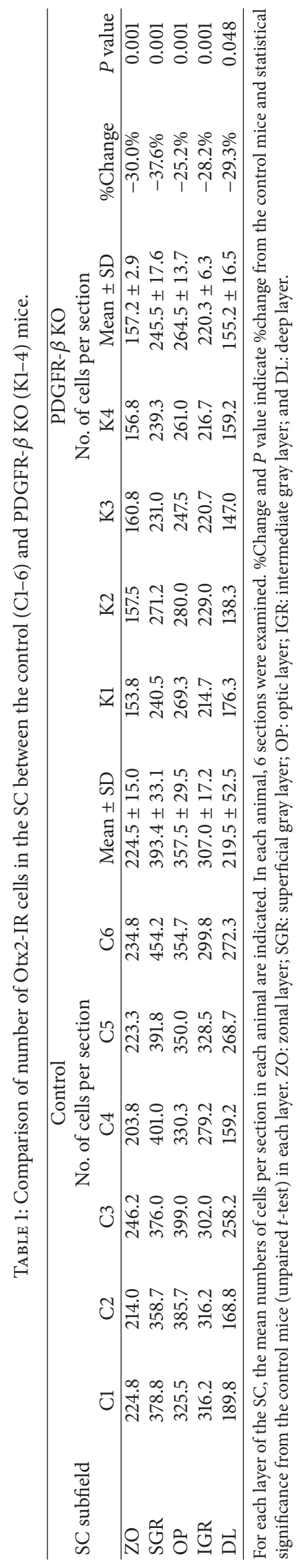




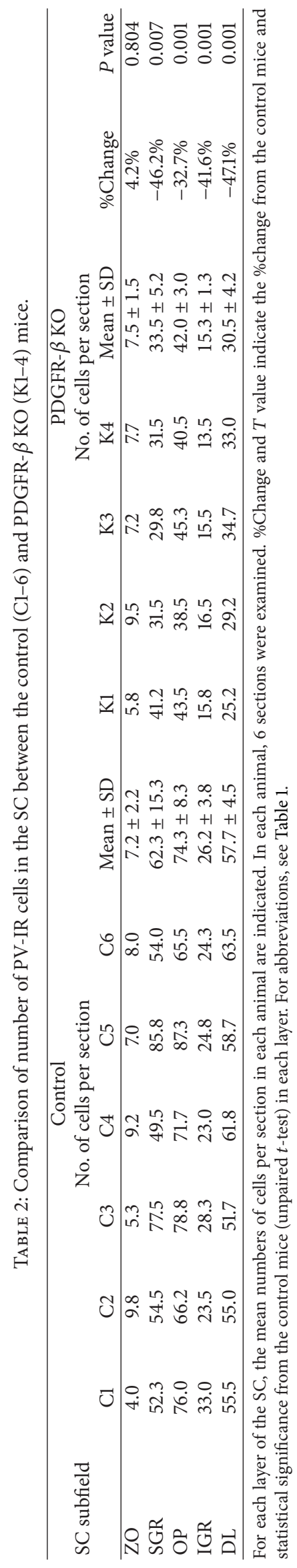


KO (PV)

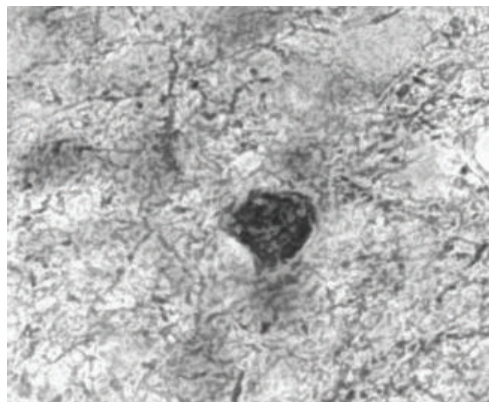

(a)

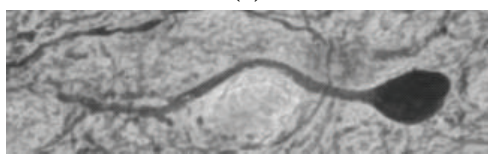

(c)

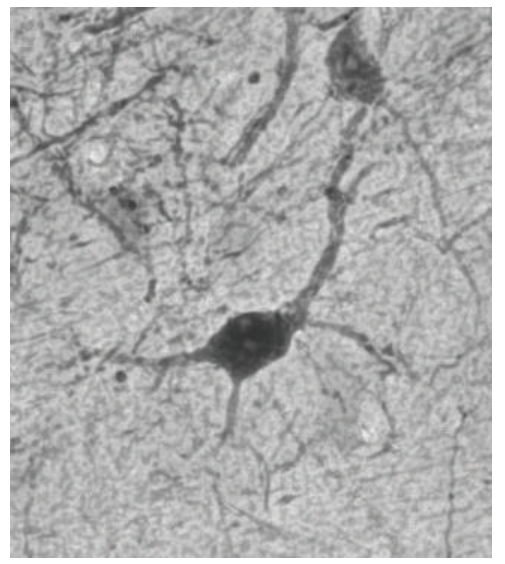

(e)

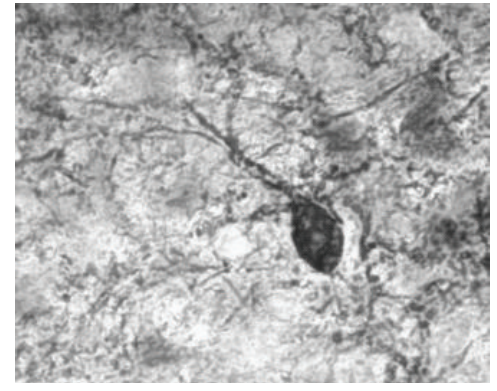

(b)

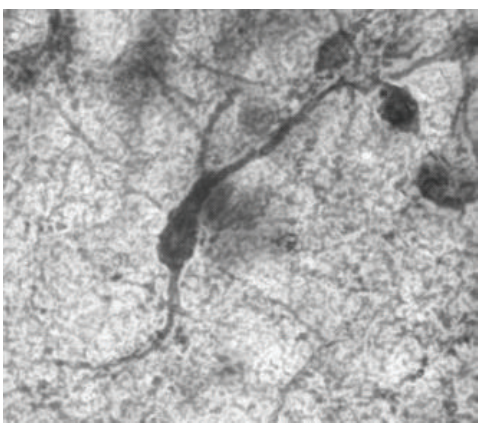

(d)

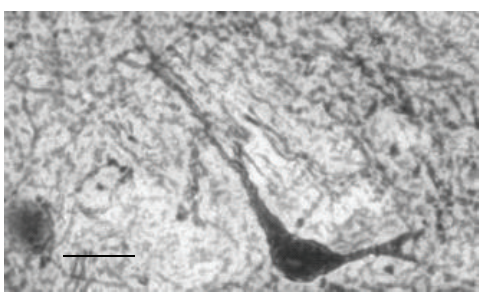

(f)

FIGURE 7: Representative examples of high-magnification photomicrographs of PV-IR cells in the KO mouse SC. (a) Marginal PV-IR cell in the deep superficial gray (SGR). (b), (c) Pyriform cells in the SGR and optic (OP), respectively. (d) Vertical fusiform cell in the SGR. (e): Multipolar cell in the deep layers (DLs). (f) Horizontal fusiform cell in the OP. Orientation of the images is dorsal to the top and lateral to the left. In all cases, scale bar $=10 \mu \mathrm{m}$.

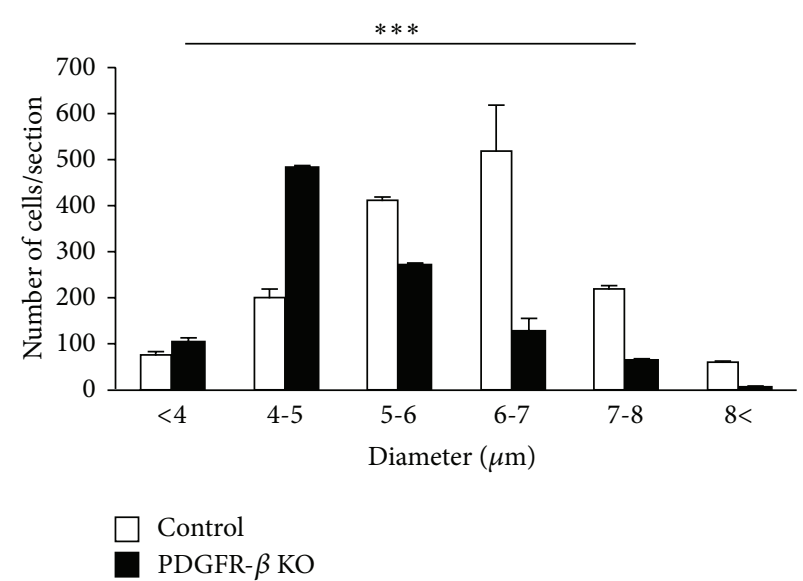

(a)

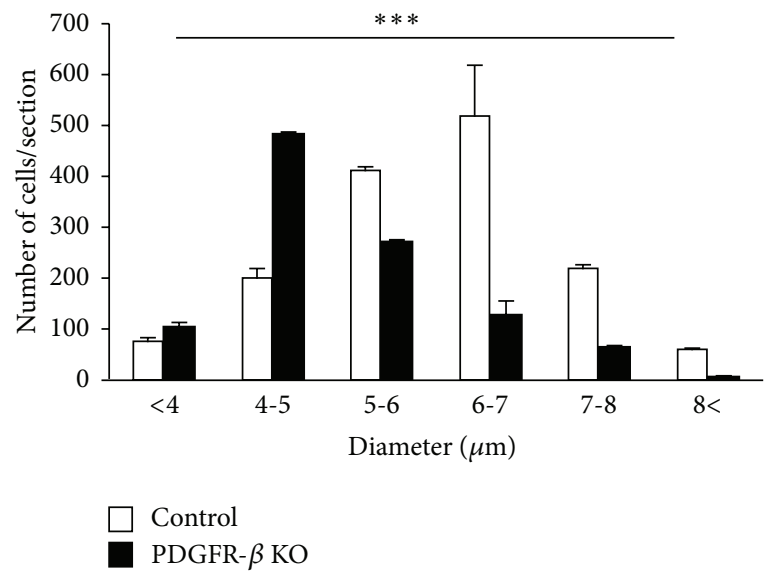

(b)

FIGURE 8: Frequency distributions of cell diameters of Otx2-IR (a) and PV-IR (b) cells in the SC of the control (open columns) and KO mice (black columns). Note that the average diameters of Otx2-IR and PV-IR cells in the SC were significantly larger in the control than those in KO mice. Error bars indicate standard deviation. ${ }^{* * *}$ Significant difference between the control and KO mice $(P<0.001$, unpaired $t$-test). 


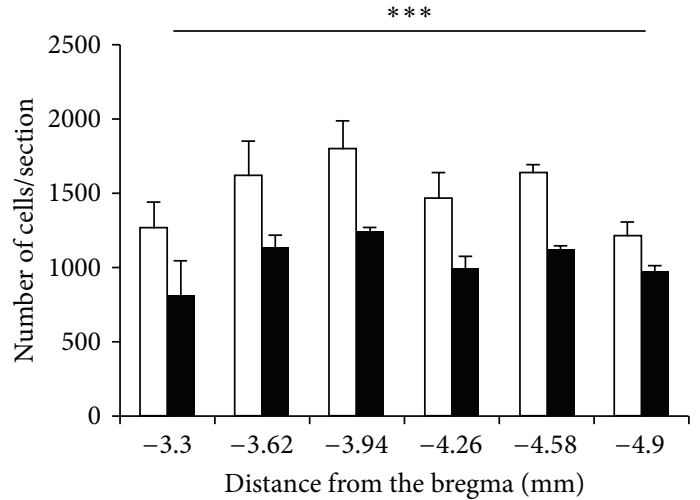

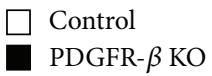

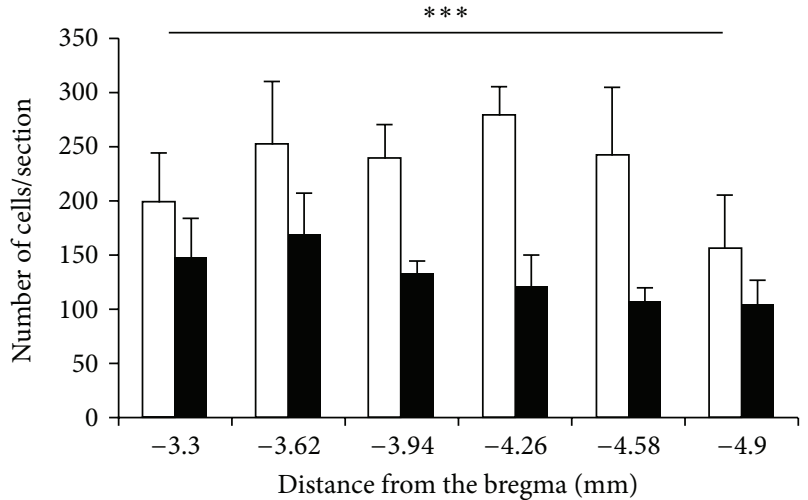

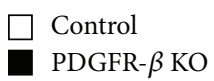

(a)

(b)

FIgURE 9: Comparison of mean number of Otx2-IR (a) and PV-IR (b) cells in the SC between the control (open columns) and KO mice (black columns). Each value represents the mean \pm SEM. Numbers below the abscissa indicate the rostrocaudal distance from the bregma. Error bars indicate standard deviation. ${ }^{* * *}$ Significant difference between the control and KO mice $(P<0.001$, repeated measures two-way ANOVA).

Furthermore, analyses by pixel intensity also revealed similar changes (data not shown).

\section{Discussion}

The present study provides the first morphological and quantitative descriptions of Otx2-IR cells in the adult mouse SC. Immunohistochemical observations of the mouse SC in the present study demonstrated that Otx2-IR cells form two main tiers (superficial and deep layers with dense and light immunoreactivity, resp.), whereas PV-IR elements are concentrated in a dense tier in the superficial layer, which represent a pattern of sublimation in the mouse SC. In addition, this study provides the first evidence for the role of PDGFR- $\beta$ in Otx 2 and PV expression in the SC.

4.1. Otx2 Expression in the SC. The dense distribution of Otx2-IR cells is observed in the superficial layers of the mouse SC, and less frequent distribution was also found in the deep layers. Presence of Otx2 expression in the postnatal SC is consistent with previous studies in rats $[30,59]$. In the present experiment, intensity of Otx2-IR labeling was different among the Otx2-IR cells. Transcription factors including Otx 2 propagate along the visual pathway by transsynaptic (cell-to-cell) transfer [30,60], and the SC receives direct afferents from the retina where the Otx 2 protein is strongly expressed $[26,30,61]$. These findings suggest that Otx2-immunoactivity in the Otx2-IR cells in the SC might be derived from the retinal ganglion cells. Therefore, strength of Otx2-immunoreactivity in individual SC neurons might be dependent on synaptic strength between the given SC neurons and retinal ganglion cells. Furthermore, a diversity of Otx 2 proteins and thier mRNA isoforms has been reported in the mouse brain [62]. This finding also supports a diversity of Otx2-immunoreactivity in the SC. Further studies are required to clarify these phenomena.

The Otx2 expression in the brain is involved in visual information processing at both prenatal and postnatal stages $[25-29,63]$, and its role in differentiation of the retina $[64,65]$ has been well established. However, the exact function of Otx2 in the SC remains unclear. The superficial layers of the SC receive visual information from the retina and visual cortex and are involved in visual information processing $[1,4-6]$, while the deep SC layers play a role in integrating sensory information into motor signals that help to orient the head and body toward various stimuli and in saccadic eye movements $[1,4-6]$. On the other hand, Otx2 is involved in the positioning of the isthmic organizer and control of neuronal subtype differentiation in the mid-brain during embryogenesis $[60,66,67]$. Furthermore, Otx2 is implicated in neural plasticity of PV-IR neurons in the postnatal visual cortex [30] and in axonal navigation and shaping neuronal arbors $[60,68]$. These results suggest that Otx2 in the SC might be involved in formation and/or maintenance of precise topographical neuronal circuits such as retinotopic organization in the superficial layers $[69,70]$ and in formation and/or maintenance of neural circuits for spatially selective orientation of the body in the deep layers $[71,72]$.

4.2. $P V$ Expression in the SC. PV-IR elements were rich in all collicular layers, and superficial gray (SGR) was homogeneously stained. The staining is attributed to rich varicose neuropils as well as a population of vertically oriented cells with a similar shape, which were more numerous in the dorsal optic (OP) than in the ventral SGR. In contrast to the staining pattern in the superficial layers, the pattern of immunoreactivity in the IGR was clustered. This pattern appears as a row of patches with various holes of different 
sizes, in which numerous marginal and multipolar cells are mostly found. The similar PV-immunolabeling patterns described in the present study are also reported in the rat SC [14]. In the superficial layers of the SC, a diffuse superposition by both PV- and Otx2-IR substances was observed, suggesting that some Otx2-IR cells coexpress PV protein. Further studies using double-labeled staining are required to confirm colocalization of Otx2- and PV-IR cells in the adult mouse SC.

In the SC, about $50 \%$ of PV-IR cells were GABAergic, and GABAergic neurons in the SC are small to medium in size (less than $15 \mu \mathrm{m}$ mean diameter) [73]. These findings are consistent with present studies in which PV-IR cells with the same size were observed. These GABAergic are involved in both intralaminar and interlaminar inhibition [74]. Consistently electrical stimulation within the superficial layers in the SC evoked inhibitory postsynaptic current [75], and projection from the superficial layers to deep layers in the SC is under tonic inhibition by GABAergic activity [74]. These GABAergic circuits are suggested to play a role in shaping receptive field inhibitory surrounds as well as visual response habituation [76] and sensorimotor processing for orientation [74]. Furthermore, PV-IR interneurons with fast spiking are involved in gamma oscillation [77, 78], which is induced in the SC by visual stimulation $[79,80]$. These findings suggest that PV-IR cells are involved in gamma oscillation in the mouse SC.

On the other hand, the remaining half of the PV-IR cells in the SC might be excitatory and colocalize with glutamate $[73,81]$. These PV-IR excitatory neurons could be excitatory projection neurons with large cell size [81] or local interneurons in the excitatory networks to generate high-frequency burst activity in premotor neurons in the intermediate layers $[73,82]$ since these premotor neurons in the intermediate layers have no intrinsic mechanisms to support high-frequency burstic activity [6].

4.3. Role of PDGFR- $\beta$ in PV and Otx2 Expression the SC. PDGF-B chain together with expression of PDGFR- $\beta$ can widely exert a neurotrophic or regulatory activity on neurons in an autocrine manner or by neuron to neuron interactions in the brain [83]. In the present study, we observed significant reductions in Otx2- and PV-IR cells in the SC of the $\mathrm{KO}$ mice. Furthermore, cell sizes of Otx2- and PV-IR cells were significantly reduced in the SC. Since Otx2-immunoreactive elements are usually localized in the nucleus of the cell body, decrease in Otx2-IR cell size might reflect decrease in expression of Otx2 protein. These findings suggest that PDGFR- $\beta$ exerts substantial effects on expression of Otx 2 and $\mathrm{PV}$ in the SC.

Since PDGF-B/PDGFR- $\beta$ signal axis exerts neurotrophic effects on GABAergic neurons $[42,45]$, a decrease in the number of PV-IR cells might be attributed to the loss of neurotrophic effects of PDGFR- $\beta$ in the PDGFR- $\beta$ KO mice. Furthermore, Otx 2 and PDGF-B/PDGFR- $\beta$ exert similar effects on neurons; both Otx2 and PDGF-B exert neurotrophic effects on dopaminergic neurons $[67,68,84]$, are involved in maturation of GABAergic neurons [30] or exert neurotrophic effects on GABAergic neurons [42, 45], and are also involved in neurogenesis and migration of some neurons $[51,67,85]$. These results suggest that effects of PDGFR$\beta$ might be partially mediated through Otx2. Consistent with this idea, Otx2 expression is controlled by neurotrophic factors such as basic fibroblast growth factor (bFGF) [86], and PDGFR- $\beta$ signals are indispensable for the bFGF signals [51]. The present results along with these previous findings suggest that PDGF-B might directly affect development of PV-IR cells, and/or indirectly affect development of PV-IR cells through its effects on Otx2. Further studies are required to elucidate signal transduction pathways among PDGFR- $\beta$, Otx2 and PV.

\section{Conclusions}

The present study demonstrates the distribution patterns of Otx2- and PV-IR cells in the mouse SC. Both the Otx2-IR cells and PV-IR elements revealed characteristic patterns. The labeled cells were heterogeneous in diameter. Although these characteristic patterns did not differ between the control and PDGFR- $\beta$ KO mice, mean numbers of the Otx2- and PV-IR cells were significantly decreased in the PDGFR- $\beta$ KO mice. Furthermore, Otx2- and PV-IR cell sizes were significantly smaller in the PDGFR- $\beta$ KO mice. These findings suggest that PDGFR- $\beta$ KO induces development and maturation deficits in Otx2- and PV-IR cells in the SC. These results further suggest that behavioral traits (socioemotional deficits) of PDGFR- $\beta$ KO mice [48] might be ascribed partly to deficits in PV-positive GABAergic neurons in the SC of PDGFR- $\beta$ $\mathrm{KO}$ mice. This idea is supported by previous studies; bilateral SC lesions reduced social behaviors $[7,8]$ and reduction of number of PV-containing GABAergic neuronsin the SC is associated with autism and schizophrenia with social deficits [17-19]. Activity in the subcortical visual pathway including the SC was altered in autistic patients [87]. Further studies are required to elucidate molecular mechanisms of the role of PDGFR- $\beta$ in survival and induction of Otx 2 and PV proteins.

\section{Acknowledgments}

This work was supported partly by JSPS Asian Core Program, and the Ministry of Education, Science, Sports and Culture, Grant-in-Aid for Scientific Research (B) (25290005).

\section{References}

[1] M. F. Huerta, A. Frankfurter, and J. K. Harting, "Studies of the principal sensory and spinal trigeminal nuclei of the rat: projections to the superior colliculus, inferior olive, and cerebellum," The Journal of Comparative Neurology, vol. 220, no. 2, pp. 147-167, 1983.

[2] J. K. Harting, W. C. Hall, I. T. Diamond, and G. F. Martin, "Anterograde degeneration study of the superior colliculus in Tupaia glis: evidence for a subdivision between superficial and deep layers," The Journal of Comparative Neurology, vol. 148, no. 3, pp. 361-386, 1973.

[3] S. B. Edwards, C. L. Ginsburgh, C. K. Henkel, and B. E. Stein, "Sources of subcortical projections to the superior colliculus in 
the cat," The Journal of Comparative Neurology, vol. 184, no. 2, pp. 309-330, 1979.

[4] R. Grantyn, "Gaze control through superior colliculus: structure and function," Reviews of Oculomotor Research, vol. 2, pp. 273333, 1988 .

[5] J. K. Harting, M. F. Huerta, T. Hashikawa, and D. P. van Lieshout, "Projection of the mammalian superior colliculus upon the dorsal lateral geniculate nucleus: organization of tectogeniculate pathways in nineteen species," The Journal of Comparative Neurology, vol. 304, no. 2, pp. 275-306, 1991.

[6] T. Isa, "Intrinsic processing in the mammalian superior colliculus," Current Opinion in Neurobiology, vol. 12, no. 6, pp. 668-677, 2002.

[7] R. S. Maior, E. Hori, C. E. Uribe et al., "A role for the superior colliculus in the modulation of threat responsiveness in primates: towards the ontogenesis of the social brain," Reviews in the Neurosciences, vol. 22, pp. 697-706, 2012.

[8] M. N. Nguyen, E. Hori, J. Matsumoto, A. H. Tran, T. Ono, and H. Nishijo, "Neuronal responses to face-like stimuli in the monkey pulvinar," The European Journal of Neuroscience, vol. 37, pp. 3551, 2013.

[9] V. A. Casagrande, "A third parallel visual pathway to primate area V1," Trends in Neurosciences, vol. 17, no. 7, pp. 305-310, 1994.

[10] I. T. Diamond, D. Fitzpatrick, and D. Schmechel, "Calcium binding proteins distinguish large and small cells of the ventral posterior and lateral geniculate nuclei of the prosimian galago and the tree shrew (Tupaia belangeri)," Proceedings of the National Academy of Sciences of the United States of America, vol. 90, no. 4, pp. 1425-1429, 1993.

[11] J. K. Johnson and V. A. Casagrande, "Distribution of calciumbinding proteins within the parallel visual pathways of a primate (Galago crassicaudatus)," The Journal of Comparative Neurology, vol. 356, no. 2, pp. 238-260, 1995.

[12] R. R. Mize, C.-J. Jeon, G. D. Butler, Q. Luo, and P. C. Emson, "The calcium binding protein calbindin-D $28 \mathrm{~K}$ reveals subpopulations of projection and interneurons in the cat superior colliculus," The Journal of Comparative Neurology, vol. 307, no. 3, pp. 417-436, 1991.

[13] D. M. Berson and J. T. McIlwain, "Retinal Y-cell activation of deep-layer cells in superior colliculus of the cat," Journal of Neurophysiology, vol. 47, no. 4, pp. 700-714, 1982.

[14] R.-B. Illing, "Association of efferent neurons to the compartmental architecture of the superior colliculus," Proceedings of the National Academy of Sciences of the United States of America, vol. 89, no. 22, pp. 10900-10904, 1992.

[15] P. S. Chard, D. Bleakman, S. Christakos, C. S. Fullmer, and R. J. Miller, "Calcium buffering properties of calbindin D28k and parvalbumin in rat sensory neurones," The Journal of Physiology, vol. 472, pp. 341-357, 1993.

[16] J. Du, L. Zhang, M. Weiser, B. Rudy, and C. J. McBain, "Developmental expression and functional characterization of the potassium-channel subunit $\mathrm{Kv} 3.1 \mathrm{~b}$ in parvalbumincontaining interneurons of the rat hippocampus," The Journal of Neuroscience, vol. 16, no. 2, pp. 506-518, 1996.

[17] D. A. Lewis, T. Hashimoto, and D. W. Volk, "Cortical inhibitory neurons and schizophrenia," Nature Reviews Neuroscience, vol. 6, no. 4, pp. 312-324, 2005.

[18] D. C. Rojas, K. Maharajh, P. Teale, and S. J. Rogers, "Reduced neural synchronization of gamma-band MEG oscillations in first-degree relatives of children with autism," BMC Psychiatry, vol. 8, article 66, 2008.
[19] G. Dendrinos, M. Hemelt, and A. Keller, "Prenatal VPA exposure and changes in sensory processing by the superior colliculus," Frontiers in Integrative Neuroscience, vol. 5, article 68, 2011.

[20] R. Finkelstein, D. Smouse, T. M. Capaci, A. C. Spradling, and N. Perrimon, "The orthodenticle gene encodes a novel homeo domain protein involved in the development of the Drosophila nervous system and ocellar visual structures," Genes \& Development, vol. 4, no. 9, pp. 1516-1527, 1990.

[21] A. Simeone, D. Acampora, M. Gulisano, A. Stornaiuolo, and E. Boncinelli, "Nested expression domains of four homeobox genes in developing rostral brain," Nature, vol. 358, no. 6388, pp. 687-690, 1992.

[22] A. Simeone, D. Acampora, A. Mallamaci et al., "A vertebrate gene related to orthodenticle contains a homeodomain of the bicoid class and demarcates anterior neuroectoderm in the gastrulating mouse embryo," The EMBO Journal, vol. 12, no. 7, pp. 2735-2747, 1993.

[23] A. Simeone, E. Puelles, and D. Acampora, "The Otx family," Current Opinion in Genetics and Development, vol. 12, no. 4, pp. 409-415, 2002.

[24] D. Arendt, "Evolution of eyes and photoreceptor cell types," International Journal of Developmental Biology, vol. 47, no. 7-8, pp. 563-571, 2003.

[25] P. Bovolenta, A. Mallamaci, P. Briata, G. Corte, and E. Boncinelli, "Implication of OTX2 in pigment epithelium determination and neural retina differentiation," The Journal of Neuroscience, vol. 17, no. 11, pp. 4243-4252, 1997.

[26] D. Baas, K. M. Bumsted, J. A. Martinez, F. M. Vaccarino, K. C. Wikler, and C. J. Barnstable, "The subcellular localization of OTX2 is cell-type specific and developmentally regulated in the mouse retina," Molecular Brain Research, vol. 78, no. 1-2, pp. 2637, 2000.

[27] J. R. Martinez-Morales, M. Signore, D. Acampora, A. Simeone, and P. Bovolenta, "Otx genes are required for tissue specification in the developing eye," Development, vol. 128, no. 11, pp. 20192030, 2001.

[28] A. S. Viczian, R. Vignali, M. E. Zuber, G. Barsacchi, and W. A. Harris, "XOtx5b and XOtx2 regulate photoreceptor and bipolar fates in the Xenopus retina," Development, vol. 130, no. 7, pp. 1281-1294, 2003.

[29] S. Sakami, O. Hisatomi, S. Sakakibara, J. Liu, T. A. Reh, and F. Tokunaga, "Downregulation of Otx2 in the dedifferentiated RPE cells of regenerating newt retina," Developmental Brain Research, vol. 155, no. 1, pp. 49-59, 2005.

[30] S. Sugiyama, A. A. di Nardo, S. Aizawa et al., "Experiencedependent transfer of Otx2 homeoprotein into the visual cortex activates postnatal plasticity," Cell, vol. 134, no. 3, pp. 508-520, 2008.

[31] F. Nothias, G. Fishell, and A. Ruiz i Altaba, "Cooperation of intrinsic and extrinsic signals in the elaboration of regional identity in the posterior cerebral cortex," Current Biology, vol. 8, no. 8, pp. 459-462, 1998.

[32] R. Ross, J. Glomset, B. Kariya, and L. Harker, "A platelet dependent serum factor that stimulates the proliferation of arterial smooth muscle cells in vitro," Proceedings of the National Academy of Sciences of the United States of America, vol. 71, no. 4, pp. 1207-1210, 1974.

[33] A. Sasahara, J. N. Kott, M. Sasahara, E. W. Raines, R. Ross, and L. E. Westrum, "Platelet-derived growth factor B-chainlike immunoreactivity in the developing and adult rat brain," Developmental Brain Research, vol. 68, no. 1, pp. 41-53, 1992. 
[34] J. Krupinski, R. Issa, T. Bujny et al., "A putative role for plateletderived growth factor in anglogenesis and neuroprotection after ischemic stroke in humans," Stroke, vol. 28, no. 3, pp. 564-573, 1997.

[35] K. Iihara, N. Hashimoto, T. Tsukahara, M. Sakata, H. Yanamoto, and T. Taniguchi, "Platelet-derived growth factor-BB, but not AA, prevents delayed neuronal death after forebrain ischemia in rats," Journal of Cerebral Blood Flow and Metabolism, vol. 17, no. 10, pp. 1097-1106, 1997.

[36] M. Ohno, M. Sasahara, S. Narumiya et al., "Expression of platelet-derived growth factor B-chain and $\beta$-receptor in hypoxic/ischemic encephalopathy of neonatal rats," Neuroscience, vol. 90, no. 2, pp. 643-651, 1999.

[37] D. A. Rappolee, C. A. Brenner, R. Schultz, D. Mark, and Z. Werb, "Developmental expression of PDGF, TGF- $\alpha$, and TGF- $\beta$ genes in preimplantation mouse embryos," Science, vol. 241, no. 4874, pp. 1823-1825, 1988.

[38] M. Mercola, D. A. Melton, and C. D. Stiles, "Platelet-derived growth factor A chain is maternally encoded in Xenopus embryos," Science, vol. 241, no. 4870, pp. 1223-1225, 1988.

[39] A. S. Goustin, C. Betsholtz, S. Pfeifer-Ohlsson et al., "Coexpression of the sis and myc proto-oncogenes in developing human placenta suggests autocrine control of trophoblast growth," Cell, vol. 41, no. 1, pp. 301-312, 1985.

[40] L. Fredriksson, H. Li, and U. Eriksson, "The PDGF family: four gene products form five dimeric isoforms," Cytokine and Growth Factor Reviews, vol. 15, no. 4, pp. 197-204, 2004.

[41] C.-H. Heldin, A. Östman, and L. Rönnstrand, "Signal transduction via platelet-derived growth factor receptors," Biochimica et Biophysica Acta, vol. 1378, no. 1, pp. F79-F113, 1998.

[42] A. Smits, M. Kato, B. Westermark, M. Nister, C.-H. Heldin, and K. Funa, "Neurotrophic activity of platelet-derived growth factor (PDGF): rat neuronal cells possess functional PDGF $\beta$-type receptors and respond to PDGF," Proceedings of the National Academy of Sciences of the United States of America, vol. 88, no. 18, pp. 8159-8163, 1991.

[43] M. Sasahara, J. W. U. Fries, E. W. Raines et al., "PDGF B-chain in neurons of the central nervous system, posterior pituitary, and in a transgenic model," Cell, vol. 64, no. 1, pp. 217-227, 1991.

[44] M. Sasahara, S. Amano, H. Sato et al., "Normal developing rat brain expresses a platelet-derived growth factor B chain (c-sis) mRNA truncated at the $5^{\prime}$ end," Oncogene, vol. 16, no. 12, pp. 1571-1578, 1998.

[45] A. Smits, A. E. Ballagi, and K. Funa, "PDGF-BB exerts trophic activity on cultured GABA interneurons from the newborn rat cerebellum," European Journal of Neuroscience, vol. 5, no. 8, pp. 986-994, 1993.

[46] C.-H. Heldin and B. Westermark, "Mechanism of action and in vivo role of platelet-derived growth factor," Physiological Reviews, vol. 79, no. 4, pp. 1283-1316, 1999.

[47] J. Andrae, R. Gallini, and C. Betsholtz, "Role of plateletderived growth factors in physiology and medicine," Genes \& Development, vol. 22, no. 10, pp. 1276-1312, 2008.

[48] P. T. H. Nguyen, T. Nakamura, E. Hori et al., "Cognitive and socio-emotional deficits in platelet-derived growth factor receptor- $\beta$ gene knockout mice," PLOS ONE, vol. 6, no. 3, Article ID e18004, 2011.

[49] Z. Gao, T. Sasaoka, T. Fujimori et al., "Deletion of the PDGFR$\beta$ gene affects key fibroblast functions important for wound healing," Journal of Biological Chemistry, vol. 280, no. 10, pp. 9375-9389, 2005.
[50] Y. Ishii, T. Oya, L. Zheng et al., "Mouse brains deficient in neuronal PDGF receptor- $\beta$ develop normally but are vulnerable to injury," Journal of Neurochemistry, vol. 98, no. 2, pp. 588-600, 2006.

[51] Y. Ishii, Y. Matsumoto, R. Watanabe et al., "Characterization of neuroprogenitor cells expressing the PDGF $\beta$-receptor within the subventricular zone of postnatal mice," Molecular and Cellular Neuroscience, vol. 37, no. 3, pp. 507-518, 2008.

[52] R. R. Mize and Q. Luo, "Visual deprivation fails to reduce calbindin $28 \mathrm{kD}$ or GABA immunoreactivity in the rhesus monkey superior colliculus," Visual Neuroscience, vol. 9, no. 2, pp. 157-168, 1992.

[53] M. Behan, A. Jourdain, and G. M. Bray, "Calcium binding protein (calbindin D28k) immunoreactivity in the hamster superior colliculus: ultrastructure and lack of co-localization with GABA," Experimental Brain Research, vol. 89, no. 1, pp. 115124, 1992.

[54] M. Abercrombie, "Estimation of nuclear population from microtome sections," The Anatomical Record, vol. 94, pp. 239247, 1946.

[55] J. C. Hedreen, "What was wrong with the Abercrombie and empirical cell counting methods? A review," The Anatomical Record, vol. 250, no. 3, pp. 373-380, 1998.

[56] T. P. Langer and R. D. Lund, "The upper layers of the superior colliculus of the rat: a Golgi study," The Journal of Comparative Neurology, vol. 158, no. 4, pp. 418-435, 1974.

[57] A. R. Labriola and L. K. Laemle, "Cellular morphology in the visual layer of the developing rat superior colliculus," Experimental Neurology, vol. 55, no. 1, pp. 247-268, 1977.

[58] K. B. Larsen, M. C. Lutterodt, K. Møllgård, and M. Møller, "Expression of the homeobox genes OTX2 and OTX1 in the early developing human brain," Journal of Histochemistry and Cytochemistry, vol. 58, no. 7, pp. 669-678, 2010.

[59] M. F. Rath, E. Muñoz, S. Ganguly et al., "Expression of the Otx2 homeobox gene in the developing mammalian brain: embryonic and adult expression in the pineal gland," Journal of Neurochemistry, vol. 97, no. 2, pp. 556-566, 2006.

[60] A. Prochiantz and A. Joliot, "Can transcription factors function as cell-cell signalling molecules?" Nature Reviews Molecular Cell Biology, vol. 4, no. 10, pp. 814-819, 2003.

[61] F. Béby, M. Housset, N. Fossat et al., "Otx2 gene deletion in adult mouse retina induces rapid RPE dystrophy and slow photoreceptor degeneration," PLoS ONE, vol. 5, no. 7, Article ID e11673, 2010.

[62] V. Courtois, G. Chatelain, Z.-Y. Han, N. le Novère, G. Brun, and T. Lamonerie, "New Otx2 mRNA isoforms expressed in the mouse brain," Journal of Neurochemistry, vol. 84, no. 4, pp. 840853, 2003.

[63] A. Nishida, A. Furukawa, C. Koike et al., "Otx2 homeobox gene controls retinal photoreceptor cell fate and pineal gland development," Nature Neuroscience, vol. 6, no. 12, pp. 1255-1263, 2003.

[64] M. E. Zuber, G. Gestri, A. S. Viczian, G. Barsacchi, and W. A. Harris, "Specification of the vertebrate eye by a network of eye field transcription factors," Development, vol. 130, no. 21, pp. 5155-5167, 2003.

[65] T. Akagi, M. Mandai, S. Ooto et al., "Otx2 homeobox gene induces photoreceptor-specific phenotypes in cells derived from adult iris and ciliary tissue," Investigative Ophthalmology and Visual Science, vol. 45, no. 12, pp. 4570-4575, 2004. 
[66] E. Puelles, A. Annino, F. Tuorto et al., "Otx2 regulates the extent, identity and fate of neuronal progenitor domains in the ventral midbrain," Development, vol. 131, no. 9, pp. 2037-2048, 2004.

[67] B. Vernay, M. Koch, F. Vaccarino et al., "Otx2 regulates subtype specification and neurogenesis in the midbrain," The Journal of Neuroscience, vol. 25, no. 19, pp. 4856-4867, 2005.

[68] C. Y. Chung, P. Licznerski, K. N. Alavian et al., "The transcription factor orthodenticle homeobox 2 influences axonal projections and vulnerability of midbrain dopaminergic neurons," Brain, vol. 133, part 7, pp. 2022-2031, 2010.

[69] M. Cynader and N. Berman, "Receptive-field organization of monkey superior colliculus," Journal of Neurophysiology, vol. 35, no. 2, pp. 187-201, 1972.

[70] U. C. Drager and D. H. Hubel, "Responses to visual stimulation and relationship between visual, auditory, and somatosensory inputs in mouse superior colliculus," Journal of Neurophysiology, vol. 38, no. 3, pp. 690-713, 1975.

[71] L. R. Burnett, B. E. Stein, D. Chaponis, and M. T. Wallace, "Superior colliculus lesions preferentially disrupt multisensory orientation," Neuroscience, vol. 124, no. 3, pp. 535-547, 2004.

[72] S. D. Crish, C. M. Dengler-Crish, and C. M. Comer, "Population coding strategies and involvement of the superior colliculus in the tactile orienting behavior of naked mole-rats," Neuroscience, vol. 139, no. 4, pp. 1461-1466, 2006.

[73] M. Behan, K. Steinhacker, S. Jeffrey-Borger, and M. A. Meredith, "Chemoarchitecture of GABAergic neurons in the ferret superior colliculus," The Journal of Comparative Neurology, vol. 452, no. 4, pp. 334-359, 2002.

[74] T. Isa and W. C. Hall, "Exploring the superior colliculus in vitro," Journal of Neurophysiology, vol. 102, no. 5, pp. 2581-2593, 2009.

[75] S. A. Neale and T. E. Salt, "Modulation of GABAergic inhibition in the rat superior colliculus by a presynaptic group II metabotropic glutamate receptor," The Journal of Physiology, vol. 577, no. 2, pp. 659-669, 2006.

[76] K. E. Binns and T. E. Salt, "Different roles for GABA(A) and $\mathrm{GABA}(\mathrm{B})$ receptors in visual processing in the rat superior colliculus," The Journal of Physiology, vol. 504, part 3, pp. 629639, 1997.

[77] E. C. Fuchs, A. R. Zivkovic, M. O. Cunningham et al., "Recruitment of parvalbumin-positive interneurons determines hippocampal function and associated behavior," Neuron, vol. 53, no. 4, pp. 591-604, 2007.

[78] V. S. Sohal, F. Zhang, O. Yizhar, and K. Deisseroth, "Parvalbumin neurons and gamma rhythms enhance cortical circuit performance," Nature, vol. 459, no. 7247, pp. 698-702, 2009.

[79] M. Breche, R. Goebel, W. Singer, and A. K. Engel, "Synchronization of visual responses in the superior colliculus of awake cats," NeuroReport, vol. 12, no. 1, pp. 43-47, 2001.

[80] Q. Pauluis, S. N. Baker, and E. Olivier, "Precise burst synchrony in the superior colliculus of the awake cat during moving stimulus presentation," The Journal of Neuroscience, vol. 21, no. 2, pp. 615-627, 2001.

[81] R. R. Mize, "Neurochemical microcircuitry underlying visual and oculomotor function in the cat superior colliculus," Progress in Brain Research, vol. 112, pp. 35-55, 1996.

[82] T. P. Trappenberg, M. C. Dorris, D. P. Munoz, and R. M. Klein, "A model of saccade initiation based on the competitive integration of exogenous and endogenous signals in the superior colliculus," Journal of Cognitive Neuroscience, vol. 13, no. 2, pp. 256-271, 2001.
[83] M. Sasahara, H. Sato, K. Iihara et al., "Expression of plateletderived growth factor B-chain in the mature rat brain and pituitary gland," Molecular Brain Research, vol. 32, no. 1, pp. 6374, 1995.

[84] A. Othberg, P. Odin, A. Ballagi, A. Ahgren, K. Funa, and O. Lindvall, "Specific effects of platelet derived growth factor (PDGF) on fetal rat and human dopaminergic neurons in vitro," Experimental Brain Research, vol. 105, no. 1, pp. 111-122, 1995.

[85] F. Inverardi, M. S. Beolchi, B. Ortino et al., "GABA immunoreactivity in the developing rat thalamus and Otx2 homeoprotein expression in migrating neurons," Brain Research Bulletin, vol. 73, no. 1-3, pp. 64-74, 2007.

[86] L. Robel, M. Ding, A. J. James et al., "Fibroblast growth factor 2 increases Otx2 expression in precursor cells from mammalian telencephalon," The Journal of Neuroscience, vol. 15, no. 12, pp. 7879-7891, 1995.

[87] N. M. Kleinhans, T. Richards, L. C. Johnson et al., "FMRI evidence of neural abnormalities in the subcortical face processing system in ASD," NeuroImage, vol. 54, no. 1, pp. 697-704, 2011. 

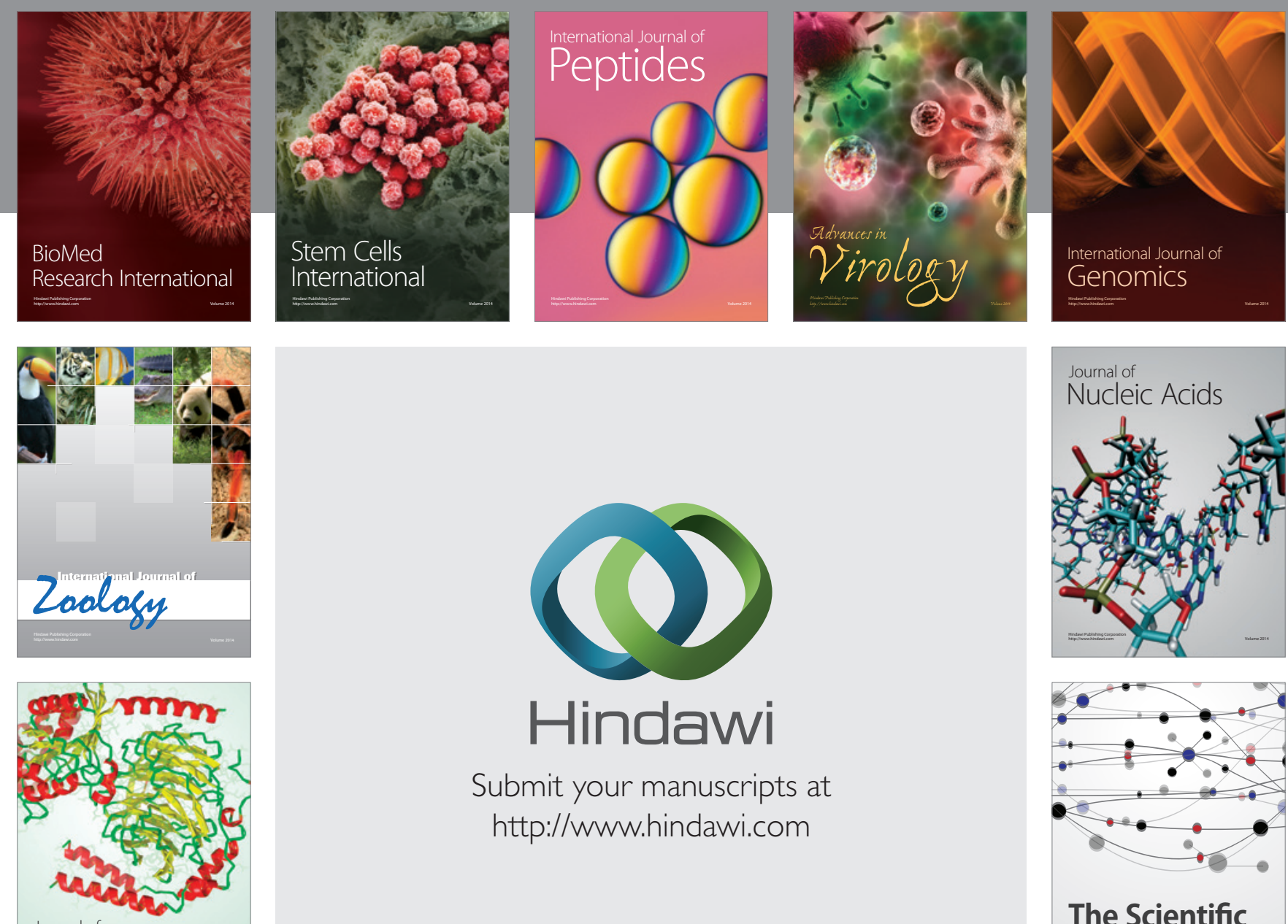

Submit your manuscripts at

http://www.hindawi.com

Journal of
Signal Transduction
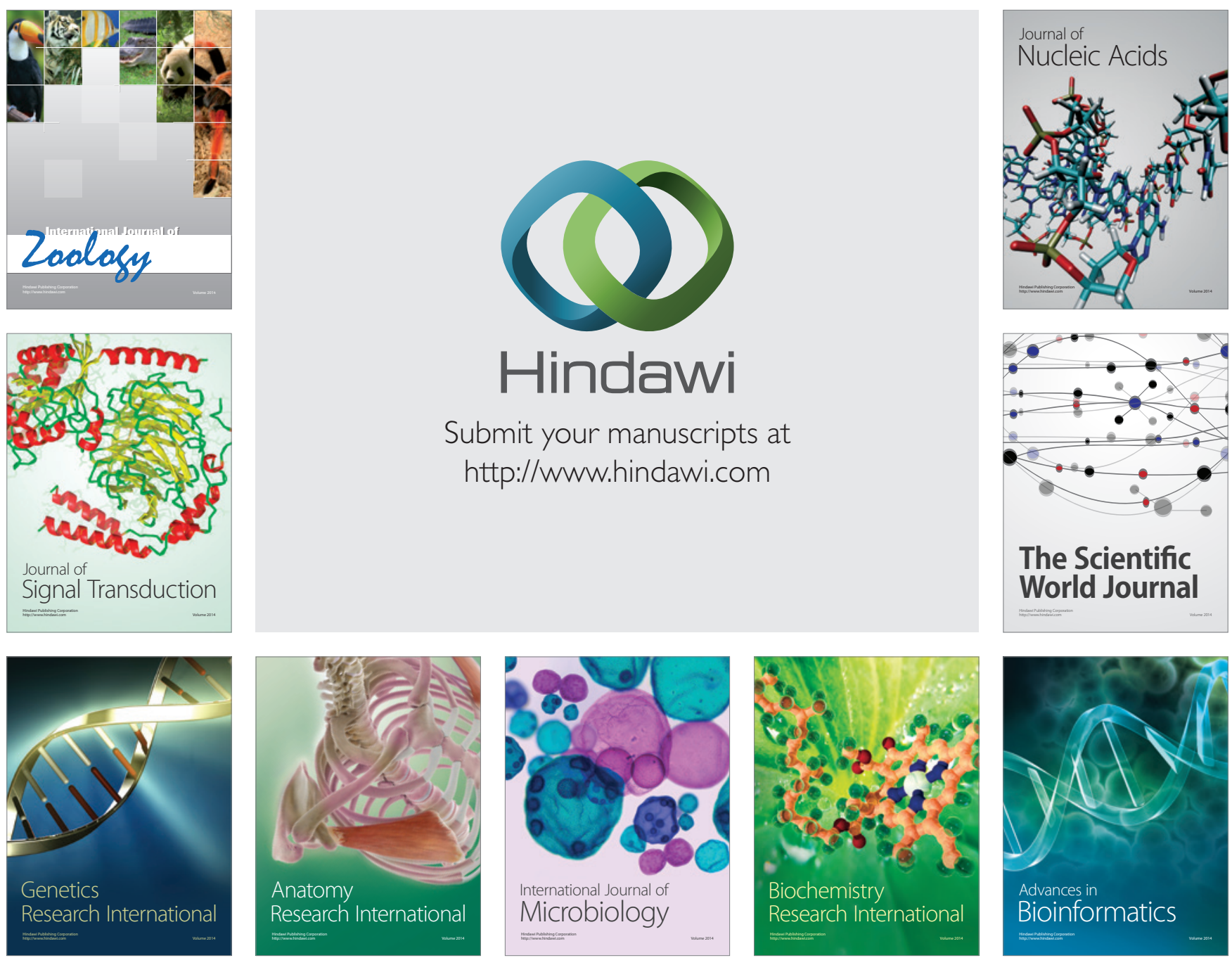

The Scientific World Journal
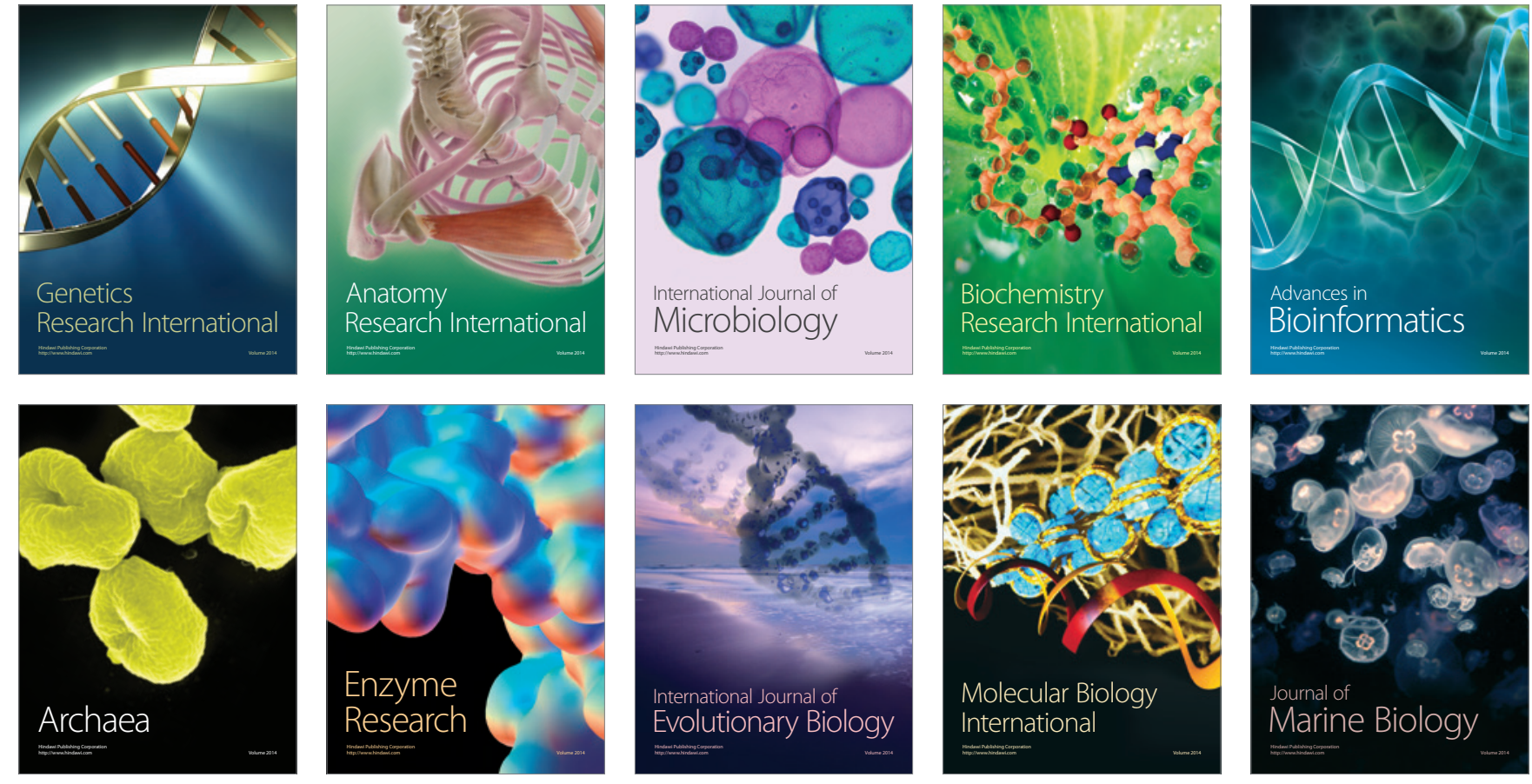